\title{
Holistic Assessment of Biochar and Brown Coal Waste as Organic Amendments in Sustainable Environmental and Agricultural Applications
}

\author{
Collins Amoah-Antwi - Jolanta Kwiatkowska-Malina • Owen Fenton • Ewa Szara • \\ Steven F. Thornton • Grzegorz Malina
}

Received: 19 December 2020 / Accepted: 4 February 2021 /Published online: 2 March 2021

(C) The Author(s) 2021

\begin{abstract}
Organic amendments can improve soil quality which has knock-on environmental and agronomic benefits. However, the use of new and emerging organic amendments such as biochar and brown coal waste $(\mathrm{BCW})$ in soil systems requires continuous holistic assessments for robust consensus building in their environmental and agricultural applications. To examine the application of BCW and woodchip biochar (BIO) in agroecosystems, secondary data from literature on environmental (soil, air and water) aspects were compiled with primary agronomic data from a 3-year multicropping field trial and collated with supplementary data on economic factors (e.g. cost and availability). For
\end{abstract}

C. Amoah-Antwi $(\bowtie) \cdot$ J. Kwiatkowska-Malina

Faculty of Geodesy and Cartography, Warsaw University of

Technology, Warsaw, Poland

e-mail: collins.amoah-antwi@pw.edu.pl

O. Fenton

Teagasc, Johnstown Castle, Environmental Research Centre, Co. Wexford, Ireland

E. Szara

Department of Agricultural Chemistry, Institute of Agriculture, Warsaw University of Life Sciences, Warsaw, Poland

\section{S. F. Thornton}

Kroto Research Institute, University of Sheffield, Sheffield S10 2TN, UK

G. Malina

AGH University of Science and Technology, Krakow, Poland the field trial, replicated plots were amended with FYM (for comparative reasons), $\mathrm{BCW}$ and $\mathrm{BIO}$ at 30, 24.2 and 12.8 for $\mathrm{tha}^{-1}$, respectively, with and without NPK and cultivated in a cropping sequence of maize, potato and barley. At the end of each season, soils were characterised for $\mathrm{pH}$, cation exchange capacity (CEC) and fertility (macronutrient contents) in addition to nutrient uptake, nutritional quality and yield of crops. Compared with FYM, biochar and BCW were found to be associated with greater improvements in soil quality (e.g. building of soil structure and $\mathrm{C}$ sequestration) and knockon water and air quality benefits mainly facilitated via increased cation retention and humic-linked sorption which abated gaseous emission and mitigated nutrient and heavy metal leaching. These along with variable improvements in soil chemistry, fertility and nutrient uptake in the agronomic field trial accounted for increased mean crop yield across treatments (higher with NPK): FYM (32.7 and 71.7\%), BCW (33.5 and 60.1\%) and BIO (21.8 and 48.2\%). Additionally, biochar and BCW have lower pollutant (e.g. heavy metals) contents and were found to provide additional sustainability and net abatement cost-benefits. While the agronomic benefits of biochar and $\mathrm{BCW}$ were slightly lower compared with that of FYM, their lower environmental footprints and associated sustainability benefits are clear advantages for their adoption in environmental and agricultural applications.

Keywords Carbonised organic amendments · Soil quality $\cdot$ Multicropping field trial $\cdot$ Soil productivity . Slow nutrient release $\cdot$ Sustainability 


\section{Introduction}

Biochar and brown coal waste (BCW) have high contents of carbon (C), recalcitrant organic detritus and humic acids equipped with extensive sorption capacities which are comparable to other activated carbon alternatives (Qi et al. 2011; Soria et al. 2020). Thus, biochar and BCW improve soil quality by increasing organic matter (OM) content and sorption capacity, which enhance soil aggregation, $\mathrm{C}$ sequestration, microbial activity, nutrient retention and pollutant (e.g. heavy metals) immobilisation with knock-on effects on water and air quality (Ouyang et al. 2013; Li et al. 2018; Amoah-Antwi et al. 2020a; Pranagal and Kraska 2020). The enhanced structure, retention and slow chemical release capacities of soil can have variable positive effects on $\mathrm{CO}_{2}, \mathrm{~N}_{2} \mathrm{O}, \mathrm{NH}_{3}$ and $\mathrm{CH}_{4}$ fluxes to and then soil nutrient, heavy metal and organic pollutant fluxes to water along surface and near-surface pathways with significant consequences on climate change and water quality (Rose et al. 2016; Saha et al. 2018; Li et al. 2019). The reductions in $\mathrm{N}$ and $\mathrm{P}$ leaching following biochar and $\mathrm{BCW}$ amendment are particularly welldocumented in coarse-textured soils, and these have additional positive implications for the productivity of cropping systems (Yao et al. 2012; Liu et al. 2017).

Indeed, owing to their unique inherent properties, different types of biochar and BCW when applied to soil at specific rates can yield additional short- to long-term soil benefits (e.g. build soil organic matter (SOM) stocks and stimulate fungal diversity) which may directly influence resource availability and soil productivity (Bekele et al. 2015; Amoah-Antwi et al. 2020a). Evidence of the long-term benefits (e.g. increased soil C content and nutrient retention) of adding charred biomass or coal products to soil can be traced back to the 'terra preta' soils in the Amazon basin (500-2500 years ago) which still maintain a considerably high soil productivity after $>$ 1000 years of land abandonment (Lehmann 2007; Schulz and Glaser 2012). However, this has not been tested in empirical long-term studies, and thus, current understanding is mainly drawn from short-term studies (Eprikashvili et al. 2016; Syuhada et al. 2016).

Several studies have investigated the soil, air and water quality benefits of biochar, but consensus on its effects on soil productivity is still lacking as there have been reports of mixed crop yield responses ranging from insignificant, minor or extreme negative and positive effects (Jeffery et al. 2017; Chen et al. 2018; Tisserant and Cherubini 2019). On the other hand, the literature on the impact of
BCW amendment on crop productivity is sparse. However, inference drawn from the effects of $\mathrm{BCW}$ on attendant growth parameters (e.g. germination indices) or the effects of derivatised $\mathrm{BCW}$ applications provides exploratory evidence of potential productivity benefits (Leszczyńska and Kwiatkowska-Malina 2011; Eprikashvili et al. 2016). Consequently, some BCW-derived humates are promoted commercially as plant growth stimulants, but their impacts on nutrient cycling and crop yield are reportedly discrepant (Little et al. 2014). Again, most researchers have assessed biochar and $\mathrm{BCW}$ use in independent environmental (e.g. gaseous emissions and nutrient leaching) and agricultural contexts (e.g. soil fertility and crop yield), with limited or no connection to the associated economic factors (e.g. cost and availability) (Li et al. 2018; Tisserant and Cherubini 2019; Amoah-Antwi et al. 2020a). A holistic assessment of biochar and $\mathrm{BCW}$ which combines these three aspects in the context of sustainability will be useful for evidencebacked risk-benefit analysis by stakeholders including farmers, environmental scientists, policymakers and regulators (Fig. 1).

The objective of the present study was to holistically assess the use of new and emerging high $\mathrm{C}$ organic amendments, i.e. biochar and $\mathrm{BCW}$, in environmental and agricultural applications linked with economic factors to guide their adoption as alternatives to conventional organic amendments (e.g. FYM). Primary agronomic data from a 3-year multicropping field experiment examined the effects of a single application of woodchip biochar (BIO) and BCW on selected soil chemical properties (cation exchange capacity (CEC) and $\mathrm{pH}$ ), nutrient cycling, $\mathrm{C}$ sequestration and soil productivity (i.e. yields of corn, potato and barley). As farmyard manure (FYM) is a standard organic amendment used in these cropping systems, it was used for comparative reasons. In addition, secondary data on the environmental aspects (soil, air and water) were combined with data on economics, sustainability, long-term sustainability, application requirements and safety compliance to support the selection and application of biochar and $\mathrm{BCW}$ in agroecosystems.

\section{Materials and Methods}

\subsection{Secondary Environmental Data}

Secondary data were collated to assess the effects of biochar, BCW and FYM amendment of soil on 
environmental aspects in cropping systems using the keywords: biochar, brown coal waste, lignite, organic amendments, soil quality, sustainable agriculture, soil productivity and crop productivity to find appropriate literature. Altogether, data from a total of 38 peerreviewed papers were selected from a wide range of results. Firstly, data on the impact of biochar, $\mathrm{BCW}$ and FYM on the physical, chemical and biological properties of soil were assessed and then collated with that on the knock-on effects (positive, neutral or negative) on water and/or air quality.

\subsection{Primary Agronomic Experimental Data}

\subsubsection{Site Description}

The research was carried out at the Skierniewice Experimental Station in central Poland $\left(20^{\circ} 34^{\prime} \mathrm{E} 51^{\circ} 58^{\prime} \mathrm{N}\right)$ for three seasons from 2017 to 2019 . The region has an average annual total precipitation of $528 \mathrm{~mm}$ with highly variable mean monthly precipitation — highest from April to August - and an annual average temperature of $7.9^{\circ} \mathrm{C}$. According to the World Reference Base for Soil Resources (WRB 2015), soil from this site is classified as a Haplic Luvisol with loamy sand texture (7\% clay, $6 \%$ silt, $87 \%$ sand).

The experimental area was previously cultivated (two seasons before the trial with triticale) and had a clover cover that was cleared mechanically prior to the present study. Before setting up the experiment in 2017 , routine characterisation indicated that soil was acidic (pH 5.07) with low macronutrient contents $(0.70 \%$ total $\mathrm{N}, 39.52 \mathrm{mg} \mathrm{kg}^{-1}$ available $\mathrm{P}$ and $60.74 \mathrm{mg} \mathrm{kg}^{-1}$ available $\mathrm{K}$ ) and $0.79 \%$ total $\mathrm{C}$. The exchangeable bases (2.54 Ca, $0.28 \mathrm{Na}, 1.44 \mathrm{~K}$ and $0.88 \mathrm{Mg} \mathrm{cmol} \mathrm{kg}^{-1}$ ) and CEC $\left(5.14 \mathrm{cmol} \mathrm{kg}^{-1}\right)$ were also determined in addition to specific surface area, SSA $\left(0.75 \mathrm{~m}^{2} \mathrm{~g}^{-1}\right)$, bulk density $\left(1.75 \mathrm{~g} \mathrm{~cm}^{-3}\right)$ and water holding capacity $(27 \% \mathrm{~m} / \mathrm{m})$.

\subsubsection{Field Trial}

The commercially available biochar (BIO), obtained from Fluid Spółka Akcyjna, Poland, was derived from conifer woodchips by flash pyrolysis at $280^{\circ} \mathrm{C}$ with a temperature increase of $10^{\circ} \mathrm{C} \mathrm{min}{ }^{-1}$ and residence time of $10 \mathrm{~min}$. This technology enabled a stable autothermal anaerobic carbonisation of biochar feedstock material at an average temperature above $260^{\circ} \mathrm{C}$. The low energy requirements ensure a more sustainable and low-cost production of biochar for soil use. The $\mathrm{BCW}$ material which had a moisture content of $34 \%$ was collected from the Bełchatów Coal Mine (central Poland). The FYM was prepared from straw and cow dung and had a moisture content of $78 \%$. Typically, in multicropping systems, FYM is applied along with NPK once a year. Based on other studies (Kwiatkowska-Malina 2015; Weng et al. 2017), biochar and BCW would only be applied once or twice in a 10 -year cycle.

The trial used a $4 \times 2 \times 3$ factorial combination which comprised four treatments (unamended control, FYM, $\mathrm{BCW}$ and BIO) and two levels of NPK (0 and recommended dosages), replicated three times and maintained throughout the 3-year experimental period. Overall, there were 24 experimental plots $(5 \mathrm{~m} \times 2.5 \mathrm{~m})$ which were separated from one another by a $0.3-\mathrm{m}$ path. All organic amendments were applied to soil on plots without tillage according to the content of $\mathrm{C}$ in $30 \mathrm{tha}^{-1}$ of FYM (equivalent to $24.2 \mathrm{t} \mathrm{ha}^{-1}$ for $\mathrm{BCW}$ and 12.8 for $\mathrm{t}$ $\mathrm{ha}^{-1}$ BIO) once throughout the experimental trial 2 weeks before planting in the first season. Granulated inorganic fertilisers were added once every season to corresponding plots by broadcasting at the recommended dosages (NPK 90:26:91 kg ha ${ }^{-1}$ ) 1 week before planting crops. In the first year (2017), maize (Zea mays) was sown in late April with a spacing of $75 \mathrm{~cm}$ $\times 25 \mathrm{~cm}$ and harvested in early August. Potato (Solanum tuberosum) was planted the following year in late March and harvested in late July. Barley (Hordeum vulgare) was sown in late April 2019 and harvested in late July. The trial was conducted under rainfed conditions, and therefore, no irrigation was required.

After harvesting at the end of each season, crop yields were determined on dry matter (DM) basis. Following this, six cylindrical soil cores $(\sim 1.5 \mathrm{~m}$ apart $)$ were randomly collected from each plot (to a depth of $30 \mathrm{~cm}$ ) using a soil column cylinder auger (length $\times$ diameter $=50 \mathrm{~cm} \times 5 \mathrm{~cm}$ ). Once extracted, soil cores from the same plot were pooled together, stored in a polythene bag and transferred together with plant samples to the laboratory for chemical analyses.

\subsubsection{Plant Analyses}

Plant analyses were performed to provide data on the nutritional quality of crops and nutrient cycling (along with crop yield data). Plant samples composed of the aboveground portion ( $2 \mathrm{~cm}$ above soil surface) of five 
Fig. 1 Approach for holistic assessment of biochar and brown coal waste as organic amendments in sustainable environmental and agricultural applications

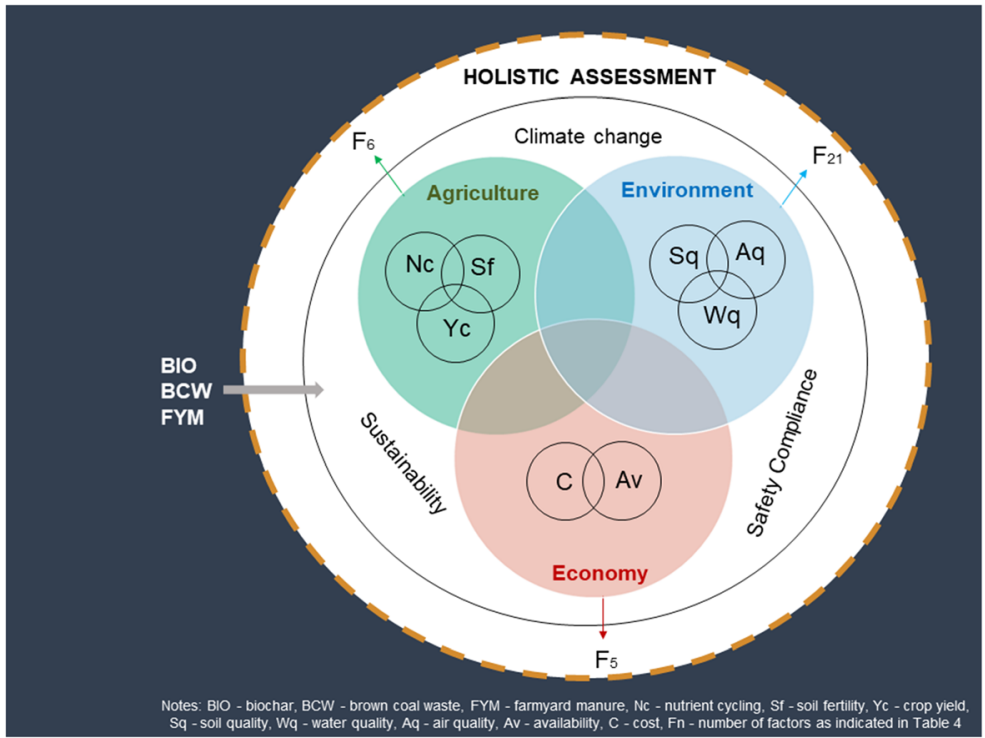

plants per plot for maize and barley and five potato tubers were randomly selected during harvesting and shaken to dislodge residual soil. In addition to grains, the blade portions of leaves beneath the uppermost ear of each maize plant were collected, whereas 5 -cm units of barley straw were sampled for further analyses. Potatoes were washed and split into four sections each. All samples were oven-dried at $60{ }^{\circ} \mathrm{C}$ for $48 \mathrm{~h}$ and milled to pass through a 2-mm sieve. Total C, N and S contents were determined by dry combustion with a Vario Micro Cube elemental analyser (Elementar Analysensysteme $\mathrm{GmbH}$, Germany) using 0.2-g samples. One-gram samples were digested by aqua regia $(3: 1 \mathrm{v} / \mathrm{v}$ of concentrated $\mathrm{HCl}: \mathrm{HNO}_{3}$ ) for the determination of $\mathrm{K}, \mathrm{Mg}$ and $\mathrm{Ca}$ by atomic absorption spectrometry (AAS) and $\mathrm{P}$ by the vanadate-molybdate colorimetric method (Sedberry et al. 1987).

\subsubsection{Analyses of Soil and Organic Amendments}

Analyses of soil and organic amendments were performed to obtain data on $\mathrm{C}$ sequestration, soil fertility, soil reaction, CEC, and metal contents of the organic amendments. The soil and organic samples were airdried for three days, passed through a 2-mm sieve and stored for further analyses. The $\mathrm{pH}$ of soil and organic amendments were measured in respective 1:2.5 and $1: 20 \mathrm{KCl}(1 \mathrm{M})$ suspensions using a $\mathrm{pH}$ metre (Schott, SI Analytics $\mathrm{GmbH}$, Germany). The $\mathrm{pH}$ of soil was converted into hydrogen ion concentration $\left[\mathrm{H}^{+}\right]$for analysis of variance using the formula:

$\left[\mathrm{H}^{+}\right]=10^{-\mathrm{pH}}$

However, mean comparisons of $\mathrm{pH}$ were made using the original experimental data. For soil $\mathrm{pH}<7$, the sum of the base cations: $\mathrm{Ca}^{2+}, \mathrm{Mg}^{2+}, \mathrm{Na}^{+}$and $\mathrm{K}^{+}\left(\mathrm{BC}_{\text {sum }}\right)$ is less than the estimated CEC due to the presence of significant amounts of acidic cations (e.g. $\mathrm{Al}^{3+}$ and $\mathrm{H}^{+}$). Therefore, considering the acidic nature of the experimental soil, hydrolytic acidity $(\mathrm{Hh})$ was used to determine the sum of acidic cations in soil by Kappen's method in $1 \mathrm{M}\left(\mathrm{CH}_{3} \mathrm{COO}\right)_{2} \mathrm{Ca}$. The $\mathrm{BC}_{\text {sum }}$ was determined in $1 \mathrm{M} \mathrm{CH}_{3} \mathrm{COONH}_{4}$ at $\mathrm{pH}$ 7.0. The $\mathrm{CEC}$ of soil was calculated as:

$\mathrm{CEC}=\mathrm{BC}_{\text {sum }}+\mathrm{Hh}$

The CEC of organic amendments was determined as $\mathrm{BC}_{\text {sum }}$ following the above procedure. The total $\mathrm{C}, \mathrm{N}$ and $\mathrm{S}$ contents of soil and organic amendments were measured by a CNS elemental analyser (Vario Micro Cube, Elementar Analysensysteme GmbH, Germany). The plant-available $\mathrm{K}, \mathrm{Mg}, \mathrm{Ca}$ and $\mathrm{P}$ contents of soil were determined by the Mehlich-3 method (Mehlich 1984; Kulhánek et al. 2014) due to its relative suitability to acidic soils than other methods (e.g. the Olsen test). The organic amendments were digested by aqua regia, and the total $\mathrm{K}, \mathrm{Mg}, \mathrm{Ca}$ and heavy metal $(\mathrm{Cd}, \mathrm{Pb}$ and $\mathrm{Zn})$ contents were determined by AAS and $\mathrm{P}$ by the vanadate-molybdate colorimetric method as described 
above for the plant samples. The SSA of the organic amendments was analysed using the Brunauer-EmmettTeller (BET) method to assess the portion of the total surface area of the material available for sorption (Batista et al. 2018).

\subsubsection{Statistics}

Statistical analyses were done only for data obtained from the primary agronomic trial, i.e. $\mathrm{pH}, \mathrm{CEC}, \mathrm{C}$ content and nutrient $(\mathrm{N}, \mathrm{P}, \mathrm{K}, \mathrm{Ca}, \mathrm{Mg}$ and $\mathrm{S})$ contents of soil, nutrient (N, P, K, Ca, Mg and $\mathrm{S}$ ) uptakes and contents of plant (maize, potato and barley) tissues and then yield (of maize, potato and barley).

The dataset was analysed for differences between means of variables using ANOVA, and their interactions were determined using the Tukey HSD post hoc test. Pearson's correlation coefficient was used to determine relationships between selected variables measured from corresponding seasons. All soil parameters were determined by analysing the factors, 'treatment' and 'year' and their interactions, whereas 'organic treatment' and 'NPK addition' and their interactions were used for analysing crop yields and contents of nutrients in plant tissues. All statistical analyses were carried out using R software (version 1.3.959), while graphs were plotted with R and GraphPad Prism (version 8.4.3).

\subsection{Holistic Assessment of Primary and Secondary Data}

Both primary and secondary data sources were collated and tabulated for biochar, BCW and FYM. Finally, economic factors, each with subfactors, were introduced to finalise the holistic assessment. These were: (i) resource availability and cost, (ii) safety compliance and (iii) application and sustainability. Local availability and on-site production of organic amendments reduce the associated transportation and in situ storage needs required to make them low-cost options and therefore considered important selection criteria (Arthurson and Jäderlund 2011). There are additional sustainability and cost-saving benefits associated with the use of high $\mathrm{C}$ and soil-stable organic amendments which can be realised through their reduced soil application rate $(\mathrm{C}$ equivalent) and frequency needs. The high moisture and pollutant contents of most organic amendments (e.g. slurry and sewage sludge) have led to low safety compliance and health concerns which have hampered their worldwide acceptance (Bai et al. 2013; Nag et al. 2020).
Thus, screening of organic amendments with low ecological footprints was considered as essential as their agronomic benefits.

\section{Results and Discussion}

\subsection{Secondary Data}

Increasing the SOM content is key to soil amelioration strategies and often the basis for the enhanced structural, hydrological and chemical responses of soil to organic amendments including biochar, BCW and FYM. Due to the high porosity and $\mathrm{C}$ contents of biochar and $\mathrm{BCW}$, they can considerably enhance $\mathrm{C}$ sequestration which improves the physical properties of soil (Amoah-Antwi et al. 2020a). For instance, the reported increases in the aggregate stability of loam soils from amendment by variable biochar types (woodchip, wheat straw and vineyard prunings) were as high as $98 \%$ in coarse-textured soils. These were accompanied by maximum increases of $38 \%$ and decreases of $13 \%$ in available water capacity and bulk density, respectively (Burrell et al. 2016). Likewise, BCW dust used to rehabilitate a post-mining silt loam to agronomic functionality resulted in increased soil porosity (19.6\%) and reduced bulk density (22.5\%) along with improvements in available water and field air capacities (Kołodziej et al. 2020). Improvements in soil structure from FYM amendment disappear quickly due to the high turnover of its labile OM proportion; otherwise, the short-term benefits are comparable to those of biochar or BCW (Amoah-Antwi et al. 2020a).

Compared with FYM, the OM and humic acids from biochar and $\mathrm{BCW}$ are more soil-stable and characterised by diverse aromatic functional groups which possess ancillary chemical retention and slow-release mechanisms, with far-reaching positive implications for heavy metal and nutrient dynamics in soil (KwiatkowskaMalina 2015; Amoah-Antwi et al. 2020a). Preliminary studies in a series investigating the utility of biochar and BCW as soil amendments showed these materials to be promising for mitigating $\mathrm{Cd}, \mathrm{Pb}$ and $\mathrm{Zn}$ bioavailability (max. 69.9, 64.3 and $17.7 \%$, respectively) in multi-element-contaminated soils (Amoah-Antwi et al. 2020b). Due to the stability of organometallic complexes formed from biochar and BCW amendment, their application for soil remediation has become very attractive (Krol- 
Domańska and Smolinska 2012; Nzediegwu et al. 2019).

Biochar and $\mathrm{BCW}$ can increase nutrient retention through sorption by humic acids in the topsoil leading to reduced subsoil nutrient stock, thus controlling and potentially mitigating nutrient leaching, especially from coarse-textured soils, to groundwater (Haider et al. 2017). For example, maximum reductions of 34.0 , 34.7 and $20.6 \%$ in leaching of $\mathrm{NO}_{3}{ }^{-}, \mathrm{NH}_{4}{ }^{+}$and $\mathrm{PO}_{4}{ }^{3-}$, respectively, from a sandy soil were found following biochar amendment (Yao et al. 2012), whereas BCW amendment increased $\mathrm{N}$ retention in a loamy sand, thereby reducing $\mathrm{NO}_{3}{ }^{-}$and $\mathrm{NH}_{4}{ }^{+}$leaching by over 20 and $40 \%$, respectively (Rose et al. 2016). Additionally, due to the high concentration of OM in the topsoil, most of the excess soil nutrients remain bound in their organic complexes and are slowly released over time for plant use, thus limiting their emission from soil (Saha et al. 2018). Consequently, biochar can reduce $\mathrm{NH}_{3}$ volatilisation by a maximum of $71 \%$, and $\mathrm{BCW}$ has been shown to reduce $\mathrm{N}_{2} \mathrm{O}$ emission by $40 \%$ (Mandal et al. 2016; Rose et al. 2016). Blending or enrichment of biochar and $\mathrm{BCW}$ with inorganic fertilisers reportedly facilitates greater retention and slow release of both native and appended soil nutrients, which enhances nutrient use efficiency while offsetting potential environmental pollution (Saha et al. 2018; Kizito et al. 2019). However, blending BCW with urea and biosolids has been found elsewhere to induce metal leaching and gaseous emissions (Paramashivam et al. 2016), and therefore, further studies are needed to determine the environmental feasibility of composite BCW (and biochar) applications.

Taken together, the carbonised amendments, biochar and $\mathrm{BCW}$, are porous and have higher contents of soilstable $\mathrm{OM}$ and humic acids with stronger sorption and slow-release mechanisms for various soil compounds compared with FYM. These make biochar and BCW more efficient for the following:

- Improving the structural and physical properties of soil

- Immobilising heavy metals and other pollutants in soil, thus reducing their bioavailability

- Reducing the emission of greenhouse gases and $\mathrm{NH}_{3}$ from soil

- Mitigating nutrient leaching into groundwater and runoff into nearby water bodies
3.2 Primary Data

\subsubsection{Soil Chemistry ( $p H$ and $C E C$ ) and $C$ Sequestration}

There were significant effects of the experimental factors, treatment and year, as well as their interaction on soil $\mathrm{pH}$ (analysed by $\left[\mathrm{H}^{+}\right]$) (Fig. 2). Throughout the study, $\left[\mathrm{H}^{+}\right]$ increased with the FYM amendment, thus leading to reductions in soil $\mathrm{pH}$ which on the other hand was increased (by approx. $0.10 \mathrm{pH}$ units) in the BIO treatments due to reduced $\left[\mathrm{H}^{+}\right]$. The $\mathrm{BCW}$ amendment increased $\left[\mathrm{H}^{+}\right]$in the first year, which then gradually declined in successive years leading to marginal soil $\mathrm{pH}$ increases in the third season, compared with the control. The addition of NPK to treatments significantly reduced soil $\mathrm{pH}$ across all treatments throughout the trial, indicating that amendments had very little controlling effects on soil $\mathrm{pH}$ which then diminished under further acidification. Continuous cropping and the seasonal losses of salts via leaching can increase soil acidity, and this is highly probable considering the loamy sand texture of the studied soil. Organic amendments can replace these salts and reduce $\mathrm{H}^{+}$and $\mathrm{Al}^{3+}$ concentrations through liming which can increase soil $\mathrm{pH}$ by up to 0.5 units yearly or $\mathrm{pH}$ buffering by enhancing surface adsorption or chelation with organic compounds (e.g. phenols) (Martinsen et al. 2014; Syuhada et al. 2016). The BIO used in this study was alkaline, and therefore, the resulting liming in the BIO treatments, even if weak, was expected. However, there were no liming effects from FYM, and this may have been due to the release of organic acids from labile OM decomposition (Aziz et al. 2017) which resulted in lower soil $\mathrm{pH}$ even when compared with the more acidic BCW. Despite this, the pattern of $\mathrm{pH}\left(\left[\mathrm{H}^{+}\right]\right)$changes in the carbonised treatments, especially the BIO, is encouraging, and the weak responses could also be due to the strong buffering properties of the acidic Haplic Luvisol (Kwiatkowska et al. 2008).

There were no significant treatment effects on CEC although trends show a higher tendency of BIO, followed by $\mathrm{BCW}$, to increase CEC compared with FYM. Given the low initial CEC of the studied soil, organic amendments were expected to increase base cations which would have resulted in substantial increases in CEC. However, significant CEC increases can take regular organic amendments over an extended period to develop in acidic soils (Fig. 3). Two factors control soil CEC: a permanent charge bespoke to the crystal 


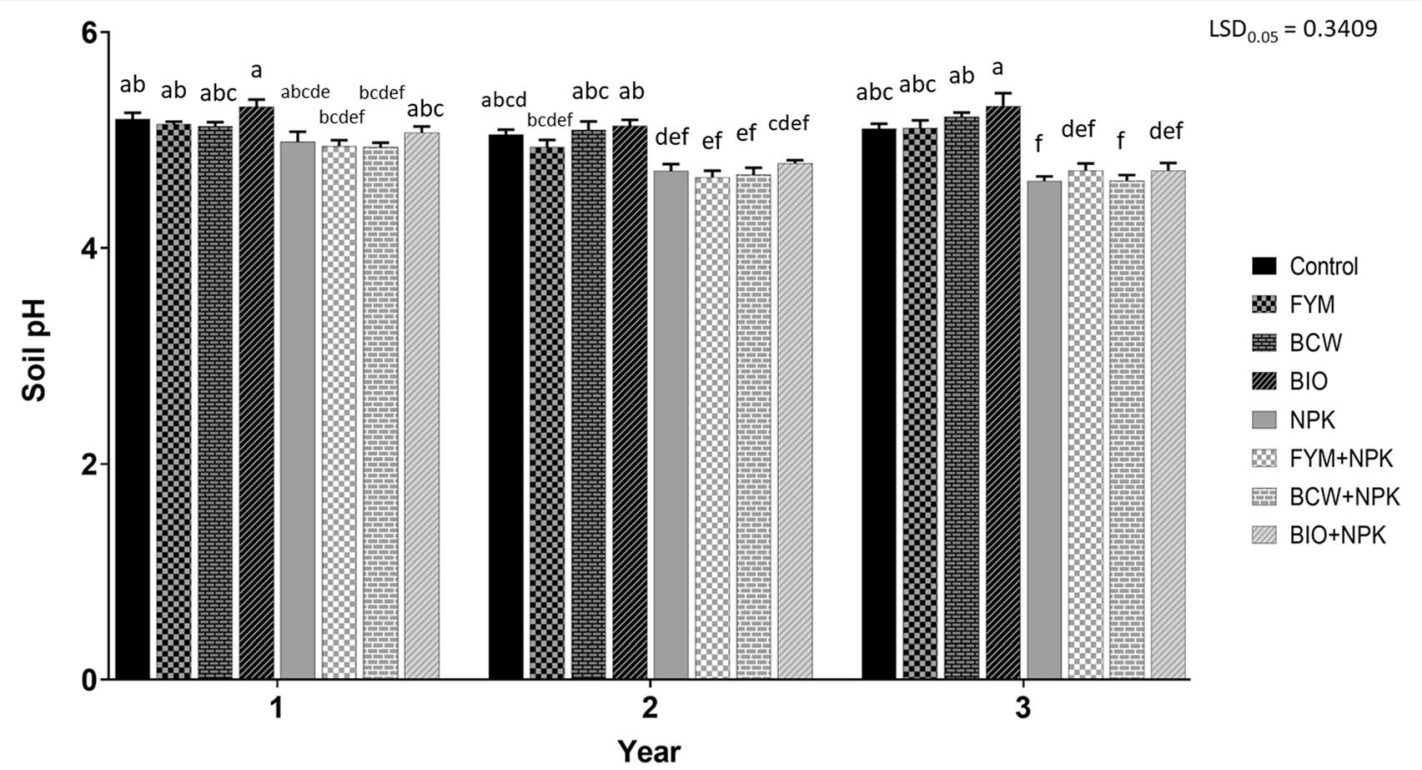

Fig 2 Effects of organic amendment on soil $\mathrm{pH}$ for three cropping seasons (2017-2019). Control, unamended treatment; FYM, farmyard manure; $B C W$, brown coal waste; $B I O$, conifer woodchip biochar; $N P K$, mineral fertiliser; $F Y M+N P K$, farmyard manure

structures of the clay minerals and a soil $\mathrm{pH}$-dependent charge resulting from ionisation of $\mathrm{H}^{+}$. The $\mathrm{pH}-$ dependent charges can be influenced by OM input but do not develop well at $\mathrm{pH}<6$ and thus fail to significantly influence the effective CEC of acidic soils (Coleman and Mehlich 1957; Dębska et al. 2002). Hence, considering that the studied soil was acidic and had high contents of acidic cations which firstly required neutralisation by base cations from the organic amendments, the lack of CEC reductions is promising from a long-term perspective for nutrient retention.

The effect of 'year' was significant on the total soil C content, whereas none was found from 'treatment' or the interaction of the two factors (Fig. 4). After OM input in soil, the decomposition of the labile fractions leads to a positive priming effect involving the mineralisation of native soil $\mathrm{C}$ which may result in a temporary decline of the total C content (Zimmerman et al. 2011) comparable to the observation in the second year of this study, especially as amendments were not reapplied. Although some studies have reported much higher biocharinduced positive priming (Luo et al. 2011), some (Kuzyakov et al. 2009) also found minor effects similar to our observation even though insignificant. Following this, a slow $\mathrm{C}$ turnover phase proceeds until a new equilibrium is established after which potential increases of the C content can be expected (Zhang et al. 2017b). and NPK; $B C W+N P K$, brown coal waste and NPK; $B I O+N P K$, conifer woodchip biochar and NPK. Bars represent mean \pm standard error of treatment, $n=3$. Different letters indicate significant differences $(p<0.05)$ between treatments

Variable outcomes using different organic amendments have been found in terms of the long-term projections of soil $\mathrm{C}$ balance beyond the equilibrium phase. For example, Clark et al. (1998) reported that increases in soil C content from manure application were only evident after 4 years compared with the substantial biochar-induced negative priming effect found after 8.2 years by Weng et al. (2017). Increases in soil C content from the BCW amendment were observed only after 2 years by Dębska et al. (2002) and 1 year by Kwiatkowska-Malina (2015), who also found after 7 years that $\mathrm{C}$ levels had declined from the 1-year highs, albeit significantly higher relative to the unamended control. Given the equivalent amounts of $\mathrm{C}$ added to soil across treatments, the inherently higher pools of recalcitrant $\mathrm{C}$ in the carbonised amendments, especially in BIO, may suggest higher soil $\mathrm{C}$ sequestration potentials and long-term soil quality benefits. Yet, significant soil $\mathrm{C}$ stocks along with soil $\mathrm{pH}$ and $\mathrm{CEC}$ increases may take several years to build for which $\mathrm{BCW}$ and $\mathrm{BIO}$ can provide advantages over FYM.

\subsubsection{Soil Fertility}

There were no significant treatment effects on the total $\mathrm{N}$ content, but significant differences were found from the factor 'year', leading to marginal reductions in total 


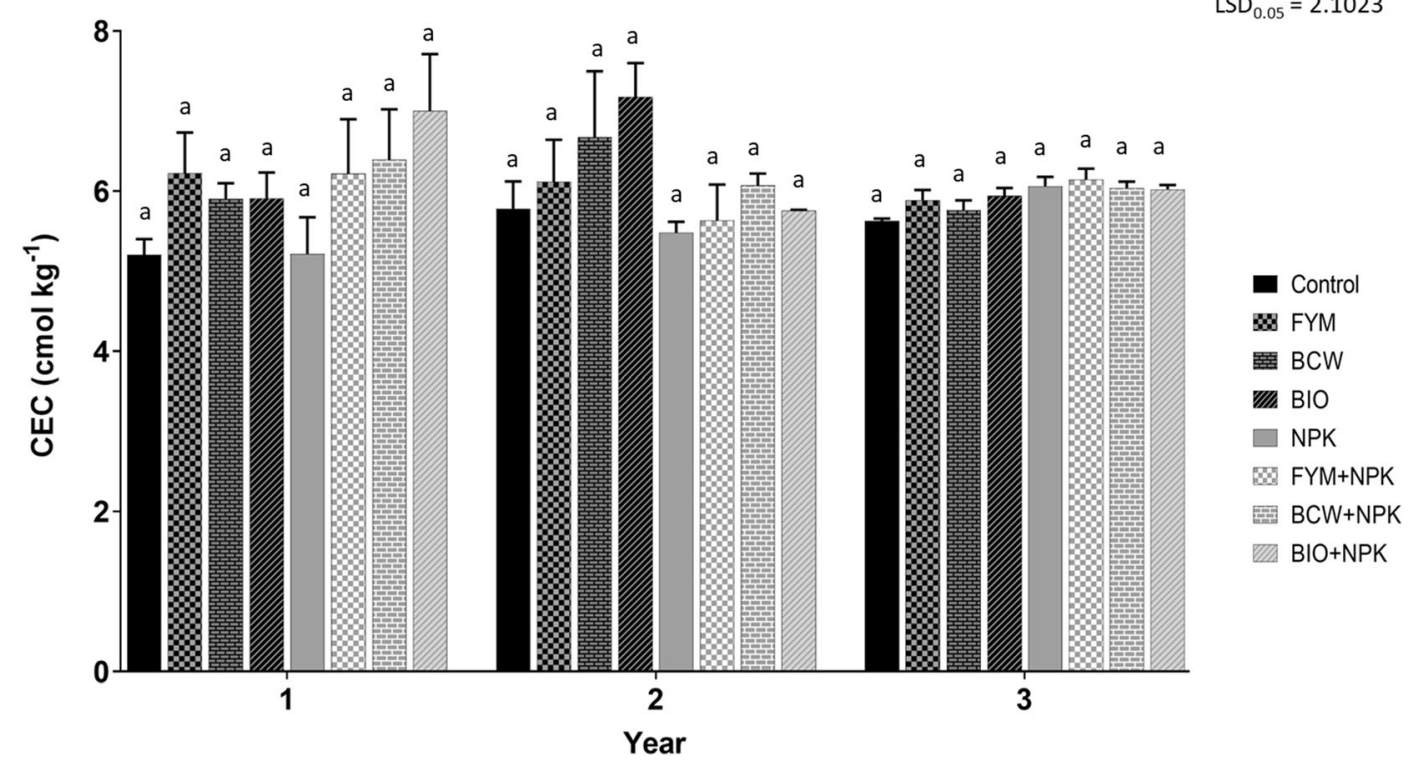

Fig 3 Effects of organic amendments on cation exchange capacity (CEC) of soil for three cropping seasons (2017-2019). Control, unamended treatment; $F Y M$, farmyard manure; $B C W$, brown coal waste; $B I O$, conifer woodchip biochar; $N P K$, mineral fertiliser; $F Y M+N P K$, farmyard manure and NPK; $B C W+N P K$, brown coal

waste and NPK; $B I O+N P K$, conifer woodchip biochar and NPK. Bars represent mean \pm standard error of treatment, $n=3$. Different letters indicate significant differences $(p<0.05)$ between treatments

$\mathrm{N}$ in the second year (Fig. 5). These trends were similar for plant-available $\mathrm{P}$, except that in this case the reductions occurred in the third season (Fig. 6). Soils with low

$\mathrm{N}$ or $\mathrm{P}$ levels are generally more responsive to amendment than those with higher levels. In the present study, the initial soil $\mathrm{N}$ was lower, whereas $\mathrm{P}$ was higher

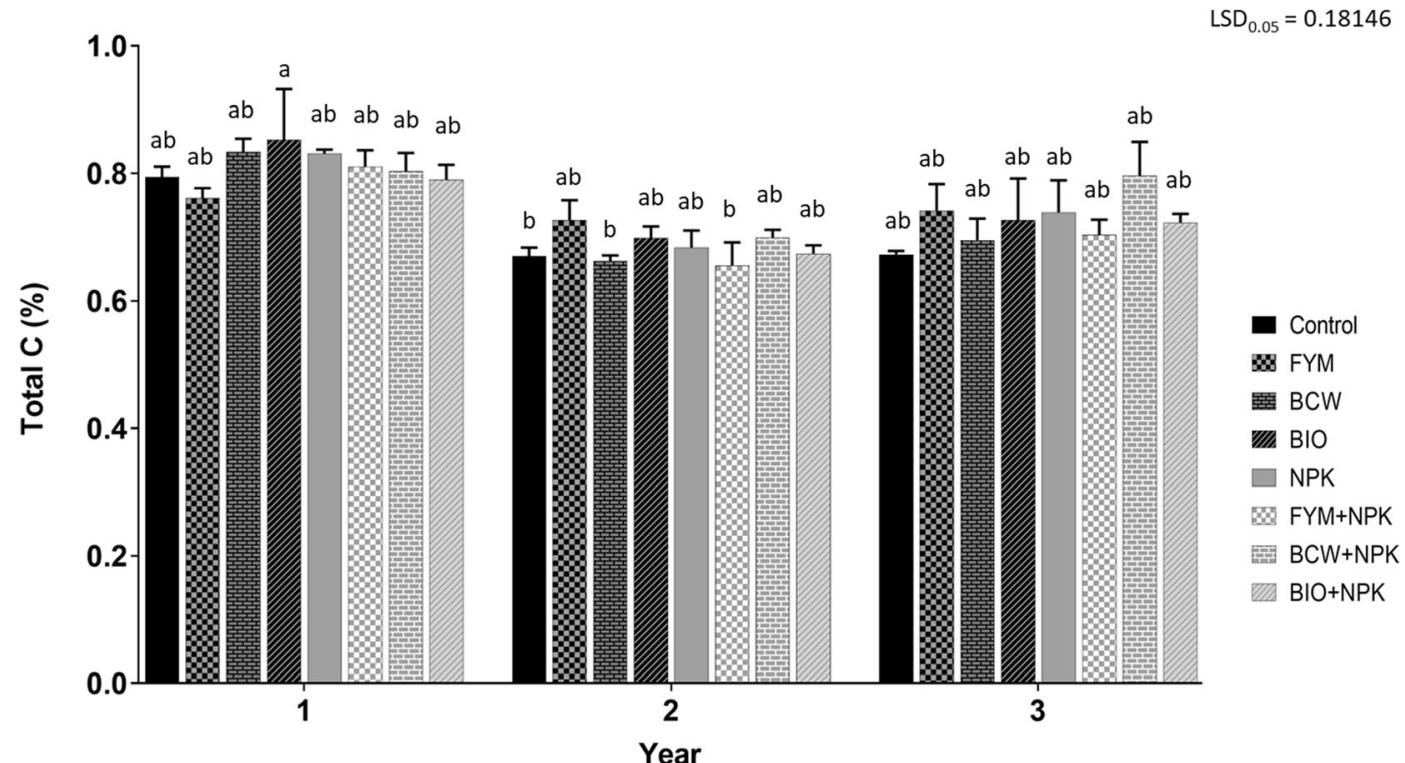

Fig 4 Effects of organic amendments on the total $\mathrm{C}$ content of soil for three cropping seasons (2017-2019). Control, unamended treatment; $F Y M$, farmyard manure; $B C W$, brown coal waste; $B I O$, conifer woodchip biochar; $N P K$, mineral fertiliser; $F Y M+N P K$, farmyard manure and NPK; $B C W+N P K$, brown coal

waste and NPK; BIO+NPK, conifer woodchip biochar and NPK. Bars represent mean \pm standard error of treatment, $n=3$. Different letters indicate significant differences $(p<0.05)$ between treatments 
compared with the minimum thresholds $(0.1 \%$ total $\mathrm{N}$ and $5 \mathrm{~g} \mathrm{mg}^{-1}$ available P) proposed by Chen et al. (2018), and therefore, relatively stronger $\mathrm{N}$ and weaker $\mathrm{P}$ responses were expected. However, it takes time to build an adequate soil nutrient retention capacity (e.g. via increased specific or non-specific adsorption for $\mathrm{P}$ or exchangeable sorption for $\mathrm{N}$ ), and therefore, the possibility of $\mathrm{N}$ or $\mathrm{P}$ leaching in the studied soils cannot be discounted. The macronutrient contents of BIO and $\mathrm{BCW}$ were low and perhaps also limited their capacity to influence $\mathrm{P}$ and $\mathrm{N}$ cycling as also shown by other studies (Tahir et al. 2011; Tran et al. 2015; Griffin et al. 2017). Charred and coal biomass, compared with fresh OM sources, are slow releasers of both native and sorbed nutrients due to their lower OM mineralisation rates (Rose et al. 2016; Liu et al. 2017). The nutrient release dynamics also depend on the formation or production conditions of the organic amendment, especially temperature. For example, pyrolysis can volatilise about $25 \%$ of the $\mathrm{N}$ pool of biochar, while $\mathrm{P}$ is also lower in high-temperature biochars (Zhang et al. 2017a; Tisserant and Cherubini 2019). The low-temperature biochar used in this study made the two most essential macronutrients relatively more available than would be in the case of a high-temperature biochar. Also, higher coalification processes produce $\mathrm{BCW}$ with lower nutrient and water contents (O'Keefe et al. 2013; Amoah-
Antwi et al. 2020a), and the BCW used in this study based on its moisture content of $34 \%$ and low levels of nutrients may have undergone moderate-to-high coalification changes. Due to the high contents of the organic-rich humic and fulvic acids in $\mathrm{BCW}$, its oxidised and composite derivatives (e.g. humate-, humalite- and lignite-based preparations) reportedly increase soil nutrient (e.g. N and P) retention (Leszczyńska and Kwiatkowska-Malina 2011; Arjumend et al. 2015; Rose et al. 2016) which is contrary to our results. However, in line with findings from this study, other experiments have also found limited $\mathrm{N}$ and $\mathrm{P}$ responses to $\mathrm{BCW}$ which are reportedly due to binding with humate ligands (Tahir et al. 2011; Bekele et al. 2015; Tran et al. 2015). Phosphorus is mostly available at soil $\mathrm{pH}$ of 6.5-7 and, even if present in high concentrations, may have been predominantly insoluble due to the high acidity of the studied soil. In contrast, FYM has been shown elsewhere to substantially increase soil N and P (Mahmood et al. 2017). Additional evidence of significant long-term $\mathrm{P}$ increases from continuous manure application ( $\geq 10$ years) has been provided by Chen et al. (2018) and perhaps points to a steady increase which may not have been perceptible in this study. Given the importance of $\mathrm{N}$ and $\mathrm{P}$ for biomass production, their residual soil contents may have been greatly impacted by plant uptake.

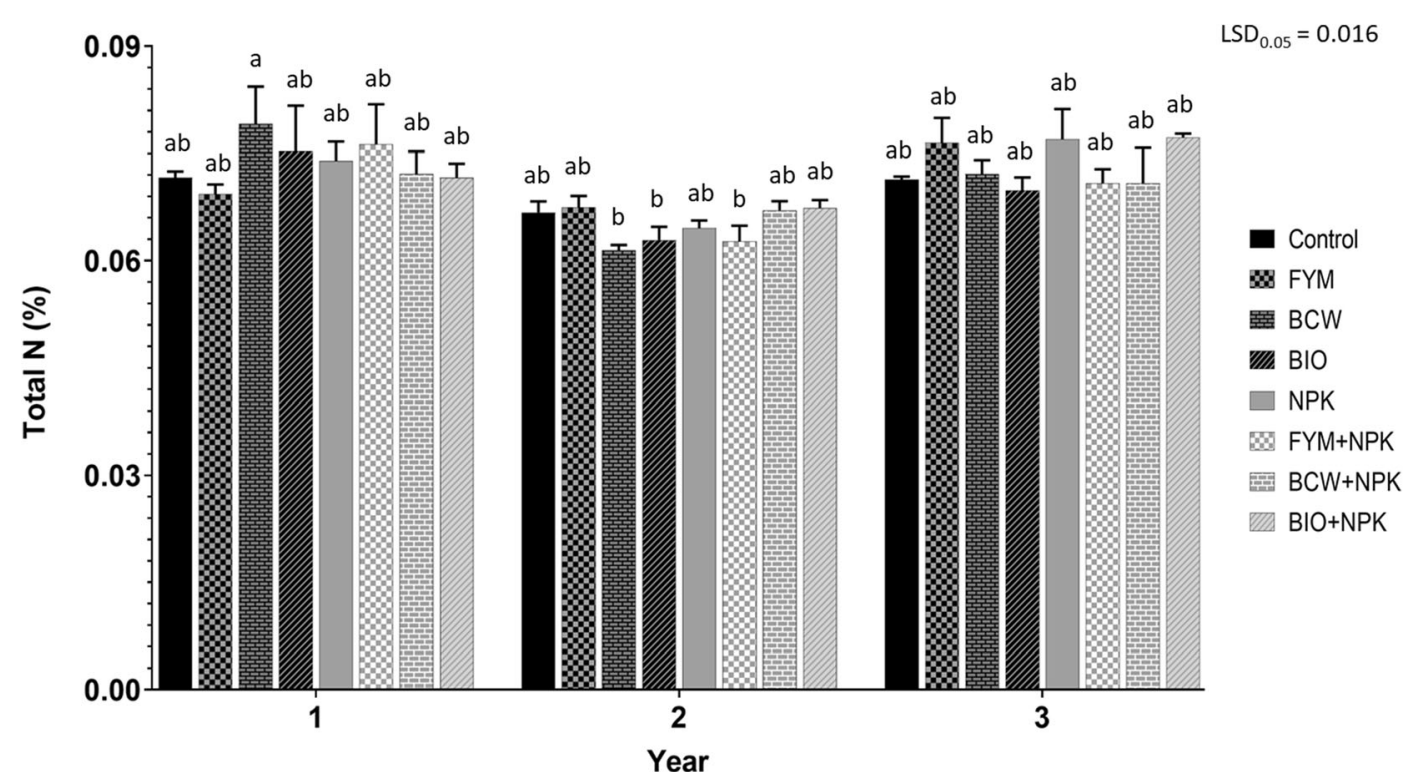

Fig. 5 Effects of organic amendments on the total $\mathrm{N}$ content of soil for three cropping seasons (2017-2019). Control, unamended treatment; $F Y M$, farmyard manure; $B C W$, brown coal waste; $B I O$, conifer woodchip biochar; $N P K$, mineral fertiliser; $F Y M+N P K$, farmyard manure and NPK; $B C W+N P K$, brown coal waste and NPK; $B I O+N P K$, conifer woodchip biochar and NPK. Bars represent mean \pm standard error of treatment, $n=3$. Different letters indicate significant differences $(p<0.05)$ between treatments 


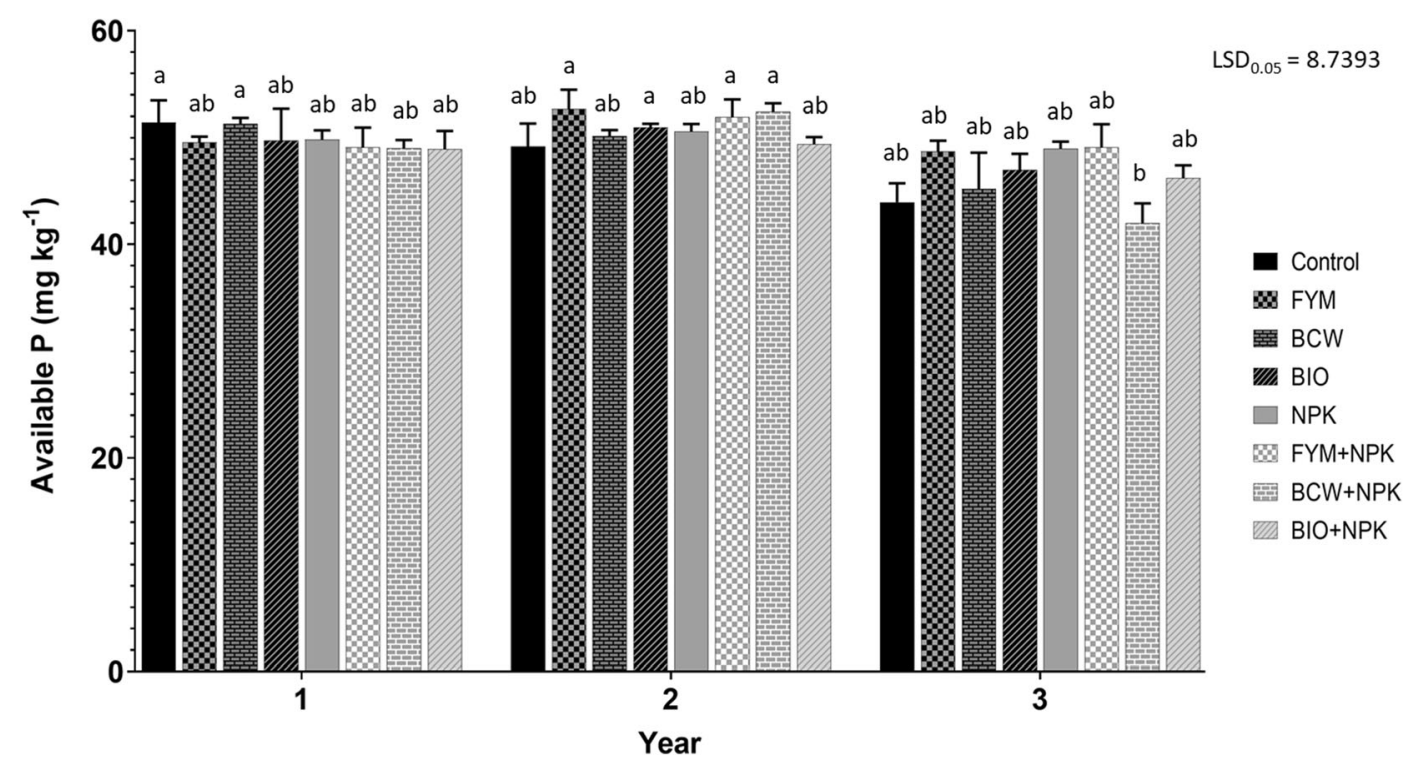

Fig. 6 Effects of organic amendments on the available P content of soil for three cropping seasons (2017-2019). Control, unamended treatment; $F Y M$, farmyard manure; $B C W$, brown coal waste; $B I O$, conifer woodchip biochar; $N P K$, mineral fertiliser; $F Y M+N P K$, farmyard manure and NPK; $B C W+N P K$, brown coal

Even without significant differences in $\mathrm{N}$ contents across treatments, the $\mathrm{C} / \mathrm{N}$ value can be used as a supplementary index to measure potential $\mathrm{N}$ mineralisation. Nitrogen mineralisation occurs steadily in soils with $\mathrm{C} /$ $\mathrm{N}$ ratios of 5-25, beyond which $\mathrm{N}$ immobilisation takes place (Gao and DeLuca 2016). Thus, soils with $\mathrm{C} / \mathrm{N}$ values of 5.6-11.3 are typically $\mathrm{N}$-rich, while complete $\mathrm{OM}$ decomposition occurs in moderately $\mathrm{N}$-rich soils with $\mathrm{C} / \mathrm{N}$ values of $15.3-20.6$, and the ratio is 37 or higher for N-deficient soils (Jia et al. 2006; Tisserant and Cherubini 2019). The calculated $\mathrm{C} / \mathrm{N}$ values in this study did not significantly differ across treatments or seasons and were found in the range 9.36-11.33 (Fig. S1), which suggests that barring extreme soil disturbances, $\mathrm{N}$ immobilisation would not be a concern. The narrow range may also imply that diversity indices of soil microorganisms actively involved in metabolic processes were low across treatments (Lemanowicz et al. 2014).

The FYM amendment led to increases in plantavailable $\mathrm{K}$ contents which increased further with NPK application except in the third season. The effects of $\mathrm{BIO}$ and $\mathrm{BCW}$ amendments were sporadic but led to $\mathrm{K}$ increases with NPK in the first and second year and then reductions, which were greater for the BIO amendment in the third year (Fig. 7). The waste and NPK; $B I O+N P K$, conifer woodchip biochar and NPK. Bars represent mean \pm standard error of treatment, $n=3$. Different letters indicate significant differences $(p<0.05)$ between treatments

plant-available $\mathrm{K}$ contents were increased in the order: $\mathrm{FYM}>\mathrm{BCW}>\mathrm{BIO}$. Like the total N, the level of available $\mathrm{K}$ content was lower in the second season. The ease of nutrient release from FYM was notably greater, thus leading to consistently higher $\mathrm{K}$ increases than from $\mathrm{BIO}$ and $\mathrm{BCW}$, and the synergy with NPK to increase available $\mathrm{K}$ is also well reported (Káš et al. 2016). The $K$ requirements of most plants, unlike $\mathrm{N}$, are low and can be adequately supplied through FYM amendment at $12-15 \mathrm{t} \mathrm{ha}^{-1}$ (Magalhães et al. 2016). Therefore, the higher FYM rate $\left(30 \mathrm{t} \mathrm{ha}^{-1}\right)$ used in this study must be in some measure responsible for the high available residual $\mathrm{K}$ content in the FYM treatments. Biochar is known to have high $\mathrm{K}$ contents, and this was confirmed by the $\mathrm{K}$ content of $\mathrm{BIO}$ being about 3 and 20 times higher compared with FYM and $\mathrm{BCW}$, respectively (Table 1). Yet, like BCW, BIO amendment had a subdued effect on soil available $\mathrm{K}$ contents, which even regressed during the study, while BCW amendment resulted in a steady $\mathrm{K}$ accretion. These observations are supported by others (Tahir et al. 2011; Gao et al. 2018) and point to slower OM turnover and nutrient release processes in BIO which are partly determined by the high lignocellulosic constitution of the studied material (Novak et al. 2018). 


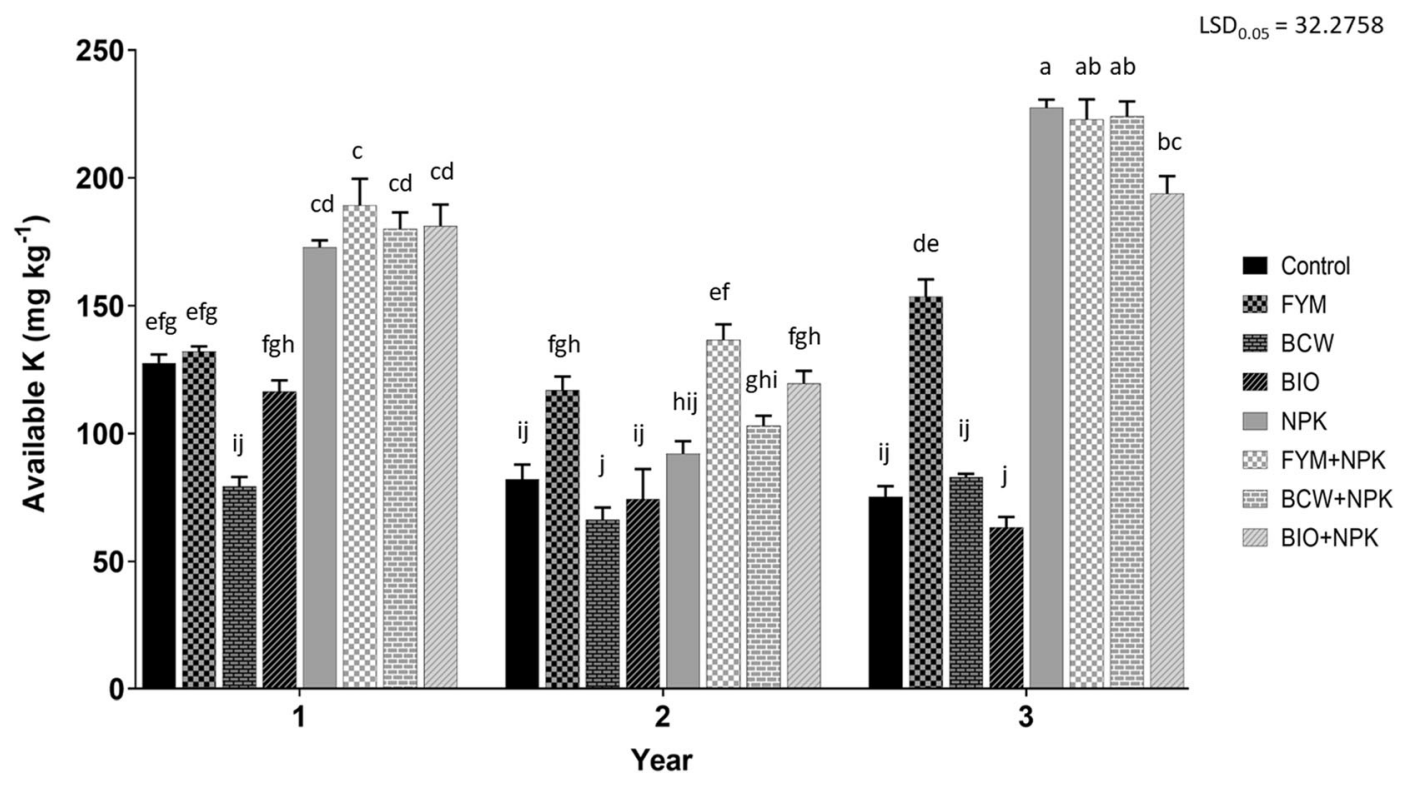

Fig. 7 Effects of organic amendments on the available K content of soil for three cropping seasons (2017-2019). Control, unamended treatment; $F Y M$, farmyard manure; $B C W$, brown coal waste; $B I O$, conifer woodchip biochar; $N P K$, mineral fertiliser; $F Y M+N P K$, farmyard manure and NPK; $B C W+N P K$, brown coal waste and NPK; BIO $+N P K$, conifer woodchip biochar and NPK. Bars represent mean \pm standard error of treatment, $n=3$. Different letters indicate significant differences $(p<0.05)$ between treatments
The FYM amendment led to the highest increases in plant-available Mg (except for a reduction with NPK addition in the second season) (Fig. 8). Without NPK addition, the $\mathrm{BCW}$ amendment had no effects on $\mathrm{Mg}$ in the first and second years, but improved in the third, while the effects of NPK were not clearly defined. With $\mathrm{BIO}, \mathrm{K}$ increased in the first 2 years but decreased in the third and led to variable responses with NPK addition. The pattern of changes in plant-available $\mathrm{Mg}$ to $\mathrm{BIO}$ and $\mathrm{BCW}$ amendments is similar to that of $\mathrm{K}$ where positive effects of BCW built steadily towards the end of the study while that of BIO withered. There were no clear treatment effects on plant-available $\mathrm{Ca}$, but an almost uniform decline across treatments was notable in the third year and was higher with NPK addition (Fig. 9). In agreement with these findings, Kulhánek et al. (2014) found increased $\mathrm{Mg}$ availability from FYM amendment accompanied by limited effects on available $\mathrm{Ca}$ which appeared to decline towards the end of a 15-year experiment. The highly variable effects of $\mathrm{BIO}$ and $\mathrm{BCW}$ on plant-available $\mathrm{Ca}$ and $\mathrm{Mg}$ lend support to some previous studies (Schulz and Glaser 2012; Tsetsegmaa et al. 2018) but also contradict others (Ciecko et al. 2015; Agegnehu et al. 2016). Soil $\mathrm{Ca}$ and $\mathrm{Mg}$ are greatly influenced by soil $\mathrm{pH}$ as they act as neutralising agents and compete with acidic cations for binding sites in the sorption complex. As shown in this study, increased acidity from NPK addition led to reductions in both elements which could be attributable to leaching of their salts (mainly calcium ammonium nitrate) (Kulhánek et al. 2014).

There were no significant treatment effects on the total soil S, but a temporal decline was clearly visible (Fig. 10). Approximately, 20\% of total S is present in the plant-available form, which according to Lemanowicz et al. (2014) should be about $25.22 \mathrm{mg}$ $\mathrm{kg}^{-1}$ to ensure a good supply to cereals. From the first to third seasons of the present study, the respective plantavailable $\mathrm{S}$ contents were within the ranges of 27.73$31.40 \mathrm{mg} \mathrm{kg}^{-1}, 22.27-25.20 \mathrm{mg} \mathrm{kg}{ }^{-1}$ and 19.20 $23.20 \mathrm{mg} \mathrm{kg}^{-1}$ across all treatments, and therefore indicated a moderate plant supply. However, the declining levels of $\mathrm{S}$ are indicative of the negative impacts of continuous cropping which were not mitigated by organic amendments. Binding sites on soil colloids are preferentially bound by $\mathrm{P}$ as opposed to $\mathrm{S}$ (Pias et al. 2019). A plausible explanation for the observed temporal reduction in $\mathrm{S}$ could be due to a lopsided competition 


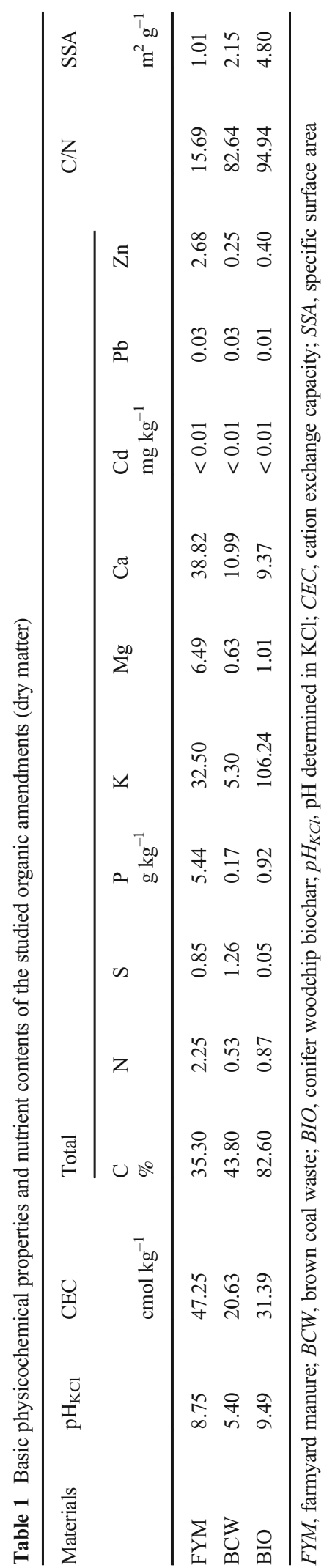

between these elements and subsequent leaching of unbound $\mathrm{S}$ beyond the sampling zone considering that $\mathrm{P}$ was several folds higher than $\mathrm{S}$ in the soil. Even with a relatively higher S content than $\mathrm{BIO}$ and $\mathrm{FYM}, \mathrm{BCW}$ has been shown to have limited impacts on soil $\mathrm{S}$ which could be related to its slow release from the coal material. Consequently, S-enriched derivatives of $\mathrm{BCW}$ have been recommended for the promotion of crop productivity (Kaya et al. 2020). Other researchers have reported considerable increases in soil S from BIO and FYM amendments (Lemanowicz et al. 2014; Bista et al. 2019), which contradict findings from this study where no significant effects were found.

General observations of the residual nutrient contents reveal a significantly enhanced macronutrient recovery with FYM (except for $\mathrm{N}$ and P), while BIO and BCW were only slightly more effective than the unamended control. Combining organic fertilisers with NPK improved available $\mathrm{K}$ and total $\mathrm{S}$ contents and reduced $\mathrm{Ca}$ and $\mathrm{Mg}$ availability, which suggests a dependence of $\mathrm{Ca}$ and $\mathrm{Mg}$ availability on high soil $\mathrm{pH}$. Positive priming effects in the second year were inferred from the declines of soil $\mathrm{C}$ contents and $\mathrm{pH}$ along with notable reductions of $\mathrm{N}, \mathrm{K}$ and $\mathrm{Mg}$ contents, which indicated the onset of a slow OM turnover phase, during which the advantages of a higher soil stability can gradually translate into significant long-term soil benefits.

\subsubsection{Nutrient Uptake and Nutritional Quality of Crops}

The FYM treatment significantly increased $\mathrm{N}$ uptakes by all crops with further increases from NPK addition, except for maize uptake which was unaffected. Yet, there were no treatment effects on the tissue $\mathrm{N}$ contents of all crops (Tables 2 and 3). In the BIO and BCW treatments, $\mathrm{N}$ uptake by all crops increased except for potato with BIO. The addition of NPK in the BIO and BCW treatments increased $\mathrm{N}$ uptake by barley but had no effect on potato uptake, whereas for maize, uptake reduced in the $\mathrm{BCW}$ treatment but was unaffected in the BIO treatment. However, just like FYM, there were no treatment effects on tissue $\mathrm{N}$ contents across all crops. The effects of the amendments on $\mathrm{N}$ uptake across the three crops were in the order: $\mathrm{BCW}>\mathrm{FYM}>\mathrm{BIO}$ and resulted in respective $37.9,34.5$ and $25.6 \%$ increases in mean uptakes which increased further with NPK addition (Table $\mathrm{S} 1$ ). With the lowest $\mathrm{C} / \mathrm{N}$ value, FYM, as compared with $\mathrm{BCW}$ and $\mathrm{BIO}$, had the highest $\mathrm{N}$ mineralisation potential (Table 1) which should have 


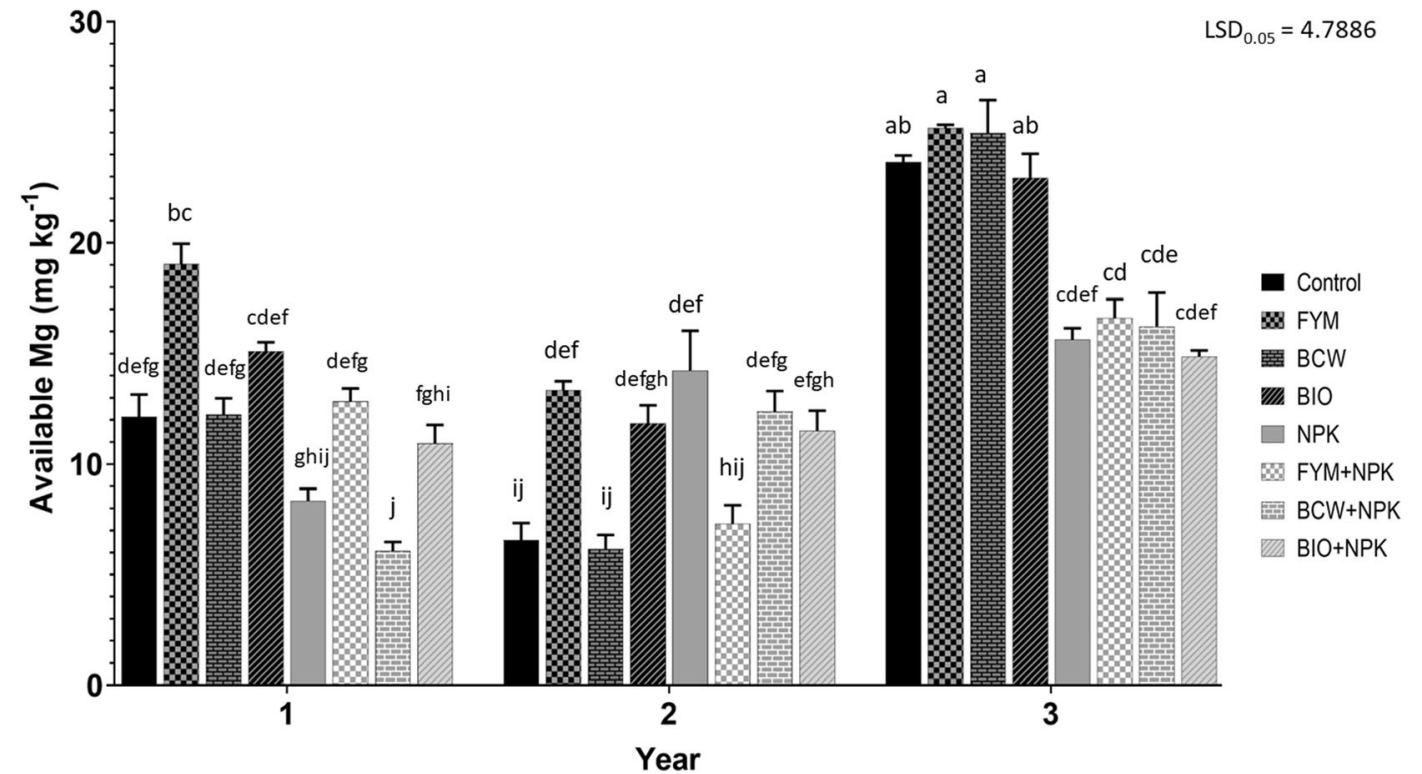

Fig. 8 Effects of organic amendments on the available Mg content of soil for three cropping seasons (2017-2019). Control, unamended treatment; $F Y M$, farmyard manure; $B C W$, brown coal waste; $B I O$, conifer woodchip biochar; $N P K$, mineral fertiliser; $F Y M+N P K$, farmyard manure and NPK; $B C W+N P K$, brown coal waste and NPK; $B I O+N P K$, conifer woodchip biochar and NPK. Bars represent mean \pm standard error of treatment, $n=3$. Different letters indicate significant differences $(p<0.05)$ between treatments

support to a strong dilution effect of crop production on tissue $\mathrm{N}$ contents. Also, many plants respond to $\mathrm{N}$ availability by reprogramming their growth through

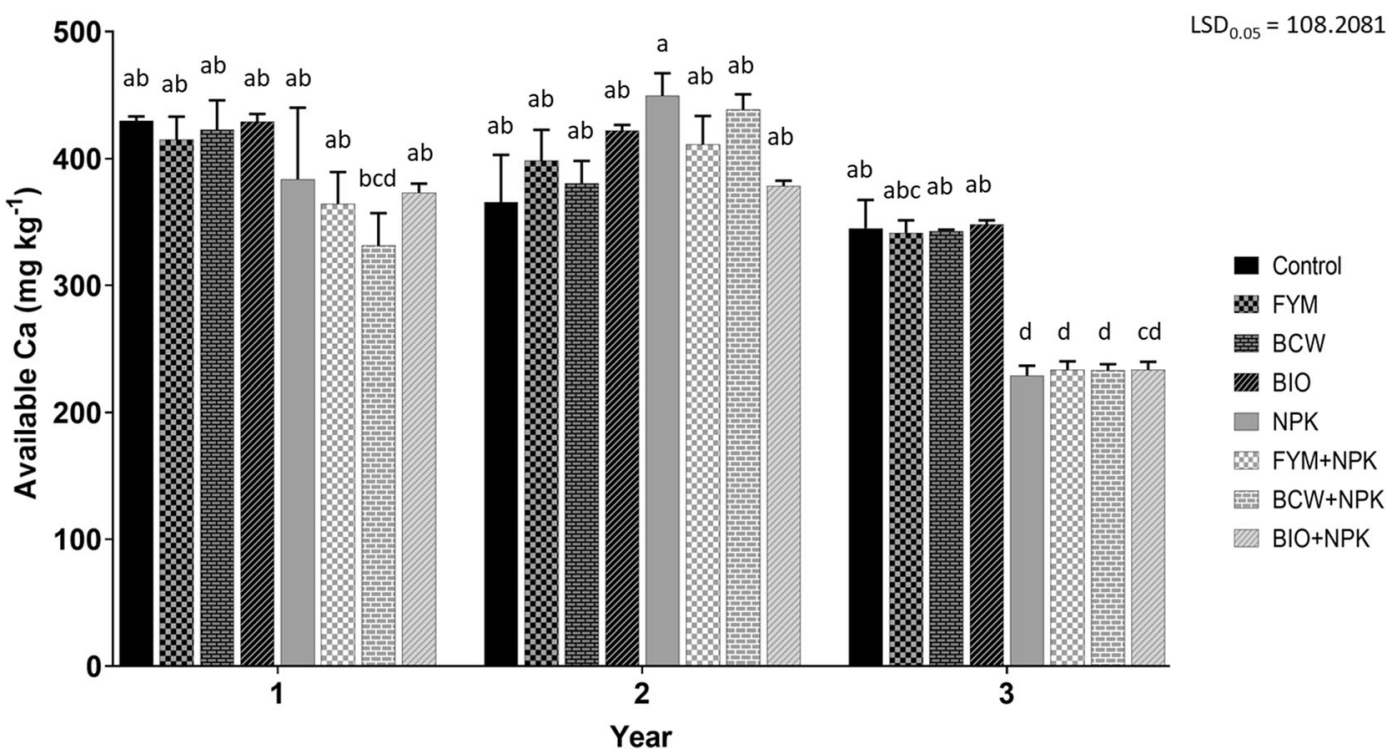

Fig. 9 Effects of organic amendments on the available Ca content of soil for three cropping seasons (2017-2019). Control, unamended treatment; $F Y M$, farmyard manure; $B C W$, brown coal waste; $B I O$, conifer woodchip biochar; $N P K$, mineral fertiliser; $F Y M+N P K$, farmyard manure and NPK; $B C W+N P K$, brown coal

waste and NPK; BIO+NPK, conifer woodchip biochar and NPK. Bars represent mean \pm standard error of treatment, $n=3$. Different letters indicate significant differences $(p<0.05)$ between treatments 
$\operatorname{LSD}_{0.05}=0.00205$

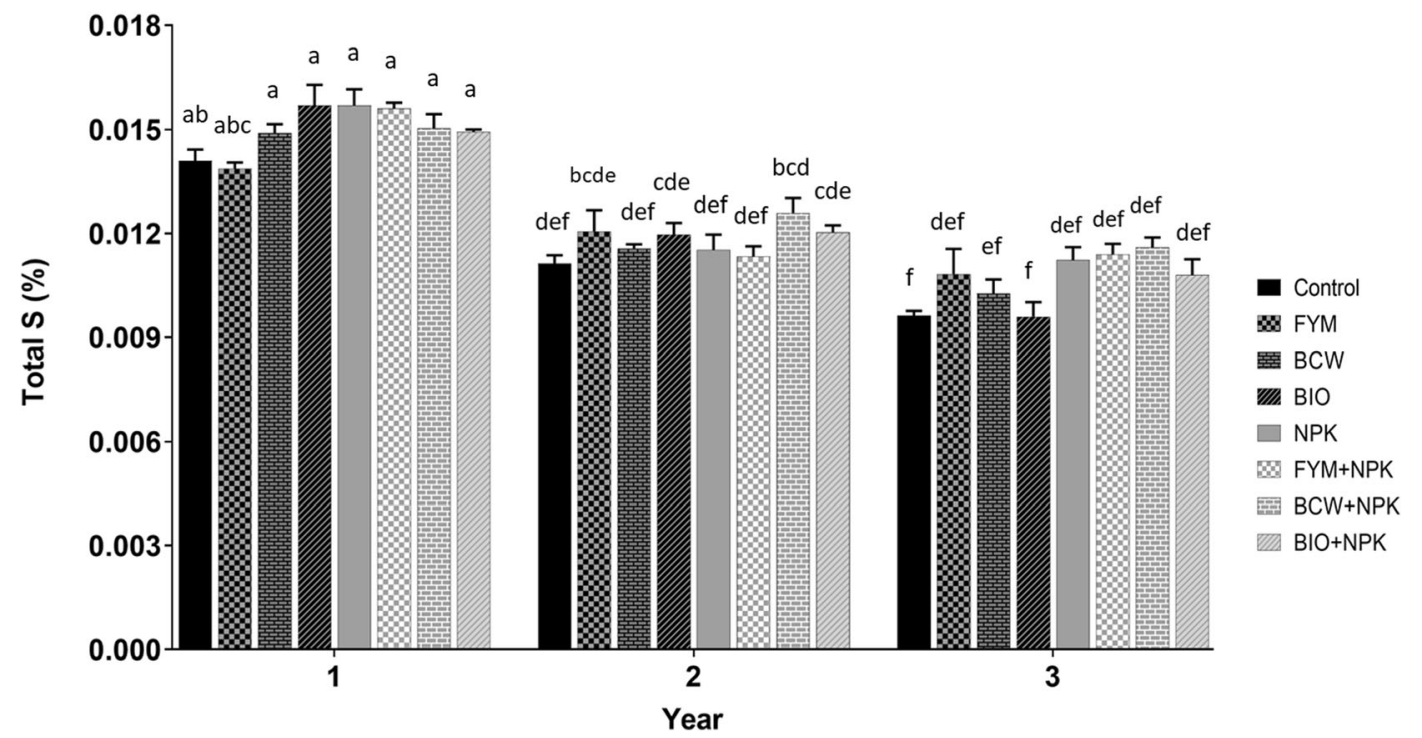

Fig. 10 Effects of organic amendments on the total S content of soil for three cropping seasons (2017-2019). Control, unamended treatment; $F Y M$, farmyard manure; $B C W$, brown coal waste; $B I O$, conifer woodchip biochar; NPK, mineral fertiliser; $F Y M+N P K$, farmyard manure and NPK; $B C W+N P K$, brown coal waste and NPK; $B I O+N P K$, conifer woodchip biochar and NPK. Bars represent mean \pm standard error of treatment, $n=3$. Different letters indicate significant differences $(p<0.05)$ between treatments modification of their root structure, vacuolar storage of $\mathrm{N}$ and distribution (Lopez-Arredondo et al. 2013). This could yet be a reason why irrespective of the amount of $\mathrm{N}$ supplied to soil by each amendment and taken up, plants adapted themselves to utilise the maximum possible, differences of which could be inferred from their respective yields and hence similar tissue $\mathrm{N}$ profiles. However, the low tissue $\mathrm{N}$ sensitivity to the studied amendments is well-reported in the literature (Belay et al. 2002; Biederman and Harpole 2013; Little et al. 2014).

The FYM treatment increased P uptake by all crops which increased further with NPK addition in maize but was unaffected in potato and barley (Table 2). This led to increased potato tuber $\mathrm{P}$ content with no effects on maize and barley grain contents, while NPK addition respectively had no effect, increased and reduced $P$ contents in the crops (Table 3). In the BIO and BCW treatments, the uptakes of $\mathrm{P}$ by all crops increased. However, NPK addition reduced the potato uptake and had no effect on barley while leading to respective increased and reduced maize uptakes in the $\mathrm{BCW}$ and $\mathrm{BIO}$ treatments. This led to increases in the $\mathrm{P}$ contents of potato tuber in both treatments, but for maize and barley, $\mathrm{BIO}$ respectively reduced and increased grain $\mathrm{P}$ contents, and these were the opposite in the $\mathrm{BCW}$ treatment. Except for a reduction in barley grain $\mathrm{P}$ content from the BCW amendment, NPK addition had no effects on the $\mathrm{P}$ contents of all crops in the BIO and $\mathrm{BCW}$ treatments. The effects of amendments on $\mathrm{P}$ uptake across the three crops were in the order: $\mathrm{BIO}>$ $\mathrm{FYM}>\mathrm{BCW}$ and led to respective 62.0, 54.3 and $41.3 \%$ increases in mean uptakes which were higher with NPK (Table S1). The effects of organic amendments on tissue uptake and content of $\mathrm{P}$ have been attributed mainly to the $\mathrm{P}$ content of the amendment material (Kizito et al. 2019). However, the trends observed in this study are inconsistent with the individual nutrient contents of the organic amendments and suggest a higher $\mathrm{P}$ use efficiency with $\mathrm{BIO}$ amendment despite its lower content of P relative to FYM (Table 1).

Amendment with FYM increased $\mathrm{K}$ uptakes by all crops, and with NPK, these were higher but not significantly different from the control (Table 2). Consequently, only the $\mathrm{K}$ contents of potato tissue increased, while those for maize and barley grains were unaffected (Table 3). Addition of NPK increased $\mathrm{K}$ in maize grain but reduced the barley grain contents and did not affect the potato contents. In the $\mathrm{BIO}$ and $\mathrm{BCW}$ treatments, $\mathrm{K}$ uptakes 
Table 2 The effects of organic amendments on the uptake of macronutrients by maize grain, potato tuber and barley grain (2017-2019 cropping seasons)

\begin{tabular}{|c|c|c|c|c|c|c|c|}
\hline Treatment & NPK & $\begin{array}{l}\mathrm{N} \\
\mathrm{kg} \mathrm{ha}^{-1}\end{array}$ & $\mathrm{~S}$ & $\mathrm{P}$ & K & $\mathrm{Mg}$ & $\mathrm{Ca}$ \\
\hline \multicolumn{8}{|l|}{ Maize grain } \\
\hline \multirow[t]{2}{*}{ Control } & No & $26.04 \pm 6.82 b$ & $1.21 \pm 0.18 \mathrm{c}$ & $9.46 \pm 1.93 \mathrm{~b}$ & $1.56 \pm 0.32 b$ & $0.29 \pm 0.05 b$ & $0.10 \pm 0.02 \mathrm{~b}$ \\
\hline & Yes & $51.60 \pm 10.39 \mathrm{a}$ & $3.23 \pm 0.36 \mathrm{a}$ & $17.79 \pm 4.01 \mathrm{ab}$ & $3.34 \pm 0.69 \mathrm{a}$ & $0.62 \pm 0.14 \mathrm{a}$ & $0.22 \pm 0.07 \mathrm{ab}$ \\
\hline \multirow[t]{2}{*}{ FYM } & No & $46.59 \pm 1.07 \mathrm{ab}$ & $1.51 \pm 0.15 \mathrm{c}$ & $16.60 \pm 1.04 \mathrm{ab}$ & $2.64 \pm 0.21 \mathrm{ab}$ & $0.52 \pm 0.06 \mathrm{ab}$ & $0.19 \pm 0.01 \mathrm{ab}$ \\
\hline & Yes & $56.38 \pm 2.19 \mathrm{a}$ & $3.44 \pm 0.04 \mathrm{a}$ & $18.58 \pm 0.77 \mathrm{a}$ & $3.43 \pm 0.29 \mathrm{a}$ & $0.63 \pm 0.05 \mathrm{a}$ & $0.31 \pm 0.03 \mathrm{a}$ \\
\hline \multirow[t]{2}{*}{$\mathrm{BCW}$} & No & $47.12 \pm 3.37 \mathrm{ab}$ & $1.73 \pm 0.25 \mathrm{bc}$ & $14.58 \pm 0.77 \mathrm{ab}$ & $2.24 \pm 0.27 \mathrm{ab}$ & $0.47 \pm 0.01 \mathrm{ab}$ & $0.19 \pm 0.01 \mathrm{ab}$ \\
\hline & Yes & $54.59 \pm 3.84 \mathrm{a}$ & $3.07 \pm 0.39 \mathrm{ab}$ & $19.09 \pm 1.11 \mathrm{a}$ & $3.39 \pm 0.32 \mathrm{a}$ & $0.63 \pm 0.04 \mathrm{a}$ & $0.32 \pm 0.03 \mathrm{a}$ \\
\hline \multirow[t]{2}{*}{$\mathrm{BIO}$} & No & $44.68 \pm 3.02 \mathrm{ab}$ & $1.48 \pm 0.40 \mathrm{c}$ & $14.01 \pm 0.43 \mathrm{ab}$ & $2.38 \pm 0.13 \mathrm{ab}$ & $0.44 \pm 0.02 \mathrm{ab}$ & $0.18 \pm 0.02 \mathrm{ab}$ \\
\hline & Yes & $45.35 \pm 4.58 \mathrm{ab}$ & $2.53 \pm 0.22 \mathrm{abc}$ & $15.98 \pm 1.49 \mathrm{ab}$ & $2.91 \pm 0.24 \mathrm{ab}$ & $0.54 \pm 0.04 \mathrm{ab}$ & $0.27 \pm 0.02 \mathrm{a}$ \\
\hline \multicolumn{2}{|l|}{$\mathrm{LSD}_{0.05}$} & 25.48 & 1.36 & 8.77 & 1.69 & 0.31 & 0.15 \\
\hline \multicolumn{8}{|l|}{ Potato tuber } \\
\hline \multirow[t]{2}{*}{ Control } & No & $75.52 \pm 1.75 b$ & $6.66 \pm 0.30 \mathrm{a}$ & $9.74 \pm 1.12 b$ & $87.86 \pm 5.30 b$ & $4.61 \pm 0.89 \mathrm{~cd}$ & $5.08 \pm 0.71 b c$ \\
\hline & Yes & $96.49 \pm 6.35 \mathrm{ab}$ & $7.66 \pm 1.09 \mathrm{a}$ & $16.65 \pm 0.65 \mathrm{a}$ & $126.39 \pm 2.33 \mathrm{a}$ & $7.97 \pm 0.54 \mathrm{~b}$ & $7.85 \pm 1.35 \mathrm{ab}$ \\
\hline \multirow[t]{2}{*}{ FYM } & No & $85.16 \pm 6.56 \mathrm{ab}$ & $6.86 \pm 0.82 \mathrm{a}$ & $15.52 \pm 0.80 \mathrm{a}$ & $116.46 \pm 3.84 \mathrm{a}$ & $6.16 \pm 0.52 b c$ & $5.67 \pm 0.75 b c$ \\
\hline & Yes & $110.03 \pm 1.76 \mathrm{a}$ & $9.03 \pm 0.68 \mathrm{a}$ & $15.91 \pm 0.85 \mathrm{a}$ & $140.73 \pm 12.42 \mathrm{a}$ & $19.29 \pm 0.24 \mathrm{a}$ & $10.05 \pm 0.26 \mathrm{a}$ \\
\hline \multirow[t]{2}{*}{$\mathrm{BCW}$} & No & $94.50 \pm 10.50 \mathrm{ab}$ & $7.82 \pm 0.41 \mathrm{a}$ & $14.48 \pm 0.55 \mathrm{ab}$ & $117.05 \pm 4.54 \mathrm{a}$ & $4.27 \pm 0.61 \mathrm{~cd}$ & $3.19 \pm 0.53 \mathrm{~cd}$ \\
\hline & Yes & $97.60 \pm 4.55 \mathrm{ab}$ & $7.39 \pm 0.53 \mathrm{a}$ & $14.47 \pm 1.37 \mathrm{ab}$ & $67.05 \pm 1.78 \mathrm{~b}$ & $2.18 \pm 0.40 \mathrm{~d}$ & $1.44 \pm 0.37 \mathrm{~d}$ \\
\hline \multirow[t]{2}{*}{$\mathrm{BIO}$} & No & $73.27 \pm 8.70 \mathrm{~b}$ & $6.23 \pm 0.56 \mathrm{a}$ & $15.87 \pm 1.43 \mathrm{a}$ & $116.06 \pm 0.82 \mathrm{a}$ & $5.07 \pm 0.60 \mathrm{bcd}$ & $4.49 \pm 0.43 \mathrm{~cd}$ \\
\hline & Yes & $82.91 \pm 6.14 \mathrm{ab}$ & $7.38 \pm 0.33 \mathrm{a}$ & $14.02 \pm 1.70 \mathrm{ab}$ & $81.40 \pm 6.13 b$ & $19.69 \pm 1.15 \mathrm{a}$ & $8.13 \pm 0.13 a b$ \\
\hline \multicolumn{2}{|l|}{$\mathrm{LSD}_{0.05}$} & 31.64 & 3.14 & 5.52 & 28.16 & 3.30 & 3.29 \\
\hline \multicolumn{8}{|l|}{ Barley grain } \\
\hline \multirow[t]{2}{*}{ Control } & No & $6.06 \pm 0.29 \mathrm{~d}$ & $0.56 \pm 0.02 b$ & $5.32 \pm 0.41 \mathrm{~b}$ & $3.21 \pm 0.18 \mathrm{~b}$ & $0.69 \pm 0.01 \mathrm{~d}$ & $0.29 \pm 0.06 \mathrm{ab}$ \\
\hline & Yes & $9.57 \pm 0.19 \mathrm{abcd}$ & $0.91 \pm 0.11 \mathrm{ab}$ & $8.87 \pm 0.80 \mathrm{ab}$ & $4.24 \pm 0.06 \mathrm{a}$ & $1.01 \pm 0.11 \mathrm{ab}$ & $0.17 \pm 0.03 \mathrm{~b}$ \\
\hline \multirow[t]{2}{*}{ FYM } & No & $7.43 \pm 1.67 \mathrm{bcd}$ & $0.68 \pm 0.06 \mathrm{ab}$ & $7.36 \pm 0.52 \mathrm{ab}$ & $4.16 \pm 0.14 \mathrm{ab}$ & $0.88 \pm 0.02 \mathrm{bcd}$ & $0.34 \pm 0.06 \mathrm{ab}$ \\
\hline & Yes & $12.22 \pm 1.35 \mathrm{ab}$ & $1.01 \pm 0.07 \mathrm{a}$ & $9.07 \pm 0.65 \mathrm{ab}$ & $4.22 \pm 0.42 \mathrm{a}$ & $1.16 \pm 0.00 \mathrm{a}$ & $0.47 \pm 0.05 \mathrm{a}$ \\
\hline \multirow[t]{2}{*}{$\mathrm{BCW}$} & No & $6.85 \pm 0.36 \mathrm{~cd}$ & $0.65 \pm 0.05 \mathrm{ab}$ & $6.74 \pm 0.91 \mathrm{ab}$ & $4.03 \pm 0.19 \mathrm{ab}$ & $0.84 \pm 0.04 \mathrm{bcd}$ & $0.39 \pm 0.07 \mathrm{ab}$ \\
\hline & Yes & $10.99 \pm 1.34 \mathrm{abc}$ & $0.95 \pm 0.12 \mathrm{ab}$ & $8.56 \pm 0.98 \mathrm{ab}$ & $4.49 \pm 0.16 \mathrm{a}$ & $1.00 \pm 0.04 \mathrm{abc}$ & $0.29 \pm 0.06 \mathrm{ab}$ \\
\hline \multirow[t]{2}{*}{$\mathrm{BIO}$} & No & $7.04 \pm 0.55 \mathrm{~cd}$ & $0.63 \pm 0.01 \mathrm{~b}$ & $9.96 \pm 0.58 \mathrm{a}$ & $3.88 \pm 0.13 \mathrm{ab}$ & $0.76 \pm 0.00 \mathrm{~cd}$ & $0.26 \pm 0.01 \mathrm{ab}$ \\
\hline & Yes & $12.92 \pm 0.98 \mathrm{a}$ & $1.02 \pm 0.07 \mathrm{ab}$ & $9.05 \pm 1.20 \mathrm{ab}$ & $4.18 \pm 0.11 \mathrm{ab}$ & $1.00 \pm 0.07 \mathrm{abc}$ & $0.32 \pm 0.03 \mathrm{ab}$ \\
\hline $\operatorname{LSD}_{0.05}$ & & 4.88 & 0.36 & 3.89 & 0.98 & 0.25 & 0.24 \\
\hline
\end{tabular}

Control, unamended treatment; $F Y M$, farmyard manure; $B C W$, brown coal waste; $B I O$, conifer woodchip biochar; $N P K$, mineral fertiliser. Values represent mean \pm standard error of treatment, $n=3$. Different letters indicate significant differences $(p<0.05)$ between treatment means

increased uniformly across all crops. The addition of NPK reduced uptakes by all crops with BIO, whereas with $\mathrm{BCW}$, uptakes by potato reduced, but both grain uptakes were unaffected. The BIO and $\mathrm{BCW}$ amendments did not affect the $\mathrm{K}$ contents of maize and barley grains, but increased the potato contents. Addition of NPK in these treatments, however, reduced $\mathrm{K}$ contents across all crops. The effects of amendment on $\mathrm{K}$ uptake across the three crops were in the order: $\mathrm{FYM}>\mathrm{BIO}>\mathrm{BCW}$ and resulted in respective $40.8,32.5$ and $32.1 \%$ increases in mean uptakes which were higher with NPK (Table S1). Like $\mathrm{P}$, the uptakes and tissue contents of $\mathrm{K}$ across all crops did not reflect the $\mathrm{K}$ contents of the organic amendments which in the case of BIO was exponentially higher compared with FYM and BCW. 
Table 3 The effects of amendments on the macronutrient contents of maize grain, potato tuber and barley grain (2017-2019 cropping seasons)

\begin{tabular}{|c|c|c|c|c|c|c|c|}
\hline \multirow[t]{2}{*}{ Treatment } & \multirow[t]{2}{*}{ NPK } & \multicolumn{6}{|l|}{ Total } \\
\hline & & $\begin{array}{l}\mathrm{N} \\
\mathrm{g} \mathrm{kg}^{-1}\end{array}$ & $\mathrm{~S}$ & $\mathrm{P}$ & $\mathrm{K}$ & $\mathrm{Mg}$ & $\mathrm{Ca}$ \\
\hline \multicolumn{8}{|l|}{ Maize grain } \\
\hline \multirow[t]{2}{*}{ Control } & No & $1.67 \pm 0.12 \mathrm{a}$ & $0.08 \pm 0.01 \mathrm{a}$ & $5.24 \pm 0.13 b$ & $1.02 \pm 0.01 \mathrm{a}$ & $0.19 \pm 0.01 \mathrm{a}$ & $0.06 \pm 0.00 \mathrm{~b}$ \\
\hline & Yes & $1.54 \pm 0.08 \mathrm{a}$ & $0.10 \pm 0.02 \mathrm{a}$ & $6.25 \pm 0.12 \mathrm{ab}$ & $1.00 \pm 0.02 \mathrm{a}$ & $0.18 \pm 0.01 \mathrm{a}$ & $0.06 \pm 0.01 \mathrm{ab}$ \\
\hline \multirow[t]{2}{*}{ FYM } & No & $1.90 \pm 0.08 \mathrm{a}$ & $0.06 \pm 0.01 \mathrm{a}$ & $5.31 \pm 0.09 \mathrm{~b}$ & $1.07 \pm 0.02 \mathrm{a}$ & $0.21 \pm 0.01 \mathrm{a}$ & $0.07 \pm 0.00 \mathrm{ab}$ \\
\hline & Yes & $1.61 \pm 0.11 \mathrm{a}$ & $0.10 \pm 0.01 \mathrm{a}$ & $6.72 \pm 0.34 \mathrm{a}$ & $0.97 \pm 0.04 \mathrm{a}$ & $0.18 \pm 0.01 \mathrm{a}$ & $0.09 \pm 0.00 \mathrm{ab}$ \\
\hline \multirow[t]{2}{*}{ BCW } & No & $1.84 \pm 0.15 \mathrm{a}$ & $0.07 \pm 0.01 \mathrm{a}$ & $5.65 \pm 0.40 \mathrm{ab}$ & $0.88 \pm 0.11 \mathrm{a}$ & $0.19 \pm 0.01 \mathrm{a}$ & $0.09 \pm 0.00 \mathrm{ab}$ \\
\hline & Yes & $1.61 \pm 0.08 \mathrm{a}$ & $0.09 \pm 0.01 \mathrm{a}$ & $5.69 \pm 0.31 \mathrm{ab}$ & $1.00 \pm 0.02 \mathrm{a}$ & $0.19 \pm 0.01 \mathrm{a}$ & $0.09 \pm 0.01 \mathrm{a}$ \\
\hline \multirow[t]{2}{*}{$\mathrm{BIO}$} & No & $1.93 \pm 0.04 \mathrm{a}$ & $0.06 \pm 0.01 \mathrm{a}$ & $5.28 \pm 0.20 \mathrm{~b}$ & $0.96 \pm 0.01 \mathrm{a}$ & $0.19 \pm 0.01 \mathrm{a}$ & $0.08 \pm 0.01 \mathrm{ab}$ \\
\hline & Yes & $1.50 \pm 0.10 \mathrm{a}$ & $0.08 \pm 0.00 \mathrm{a}$ & $6.06 \pm 0.13 \mathrm{ab}$ & $0.96 \pm 0.01 \mathrm{a}$ & $0.18 \pm 0.00 \mathrm{a}$ & $0.09 \pm 0.00 \mathrm{ab}$ \\
\hline \multicolumn{2}{|l|}{$\mathrm{LSD}_{0.05}$} & 0.49 & 0.05 & 1.18 & 0.23 & 0.04 & 0.03 \\
\hline \multicolumn{8}{|l|}{ Potato tuber } \\
\hline \multirow[t]{2}{*}{ Control } & No & $1.14 \pm 0.05 \mathrm{a}$ & $0.10 \pm 0.00 \mathrm{a}$ & $1.46 \pm 0.17 \mathrm{~b}$ & $13.26 \pm 1.13 \mathrm{ab}$ & $0.69 \pm 0.12$ cde & $0.77 \pm 0.13 a b c$ \\
\hline & Yes & $1.27 \pm 0.09 \mathrm{a}$ & $0.10 \pm 0.01 \mathrm{a}$ & $2.19 \pm 0.07 \mathrm{ab}$ & $16.64 \pm 0.19 \mathrm{a}$ & $1.05 \pm 0.06 \mathrm{c}$ & $1.03 \pm 0.17 \mathrm{ab}$ \\
\hline \multirow[t]{2}{*}{ FYM } & No & $1.13 \pm 0.07 \mathrm{a}$ & $0.09 \pm 0.01 \mathrm{a}$ & $2.06 \pm 0.14 \mathrm{ab}$ & $15.45 \pm 0.86 \mathrm{ab}$ & $0.82 \pm 0.07 \mathrm{~cd}$ & $0.75 \pm 0.09 \mathrm{abc}$ \\
\hline & Yes & $1.24 \pm 0.05 \mathrm{a}$ & $0.10 \pm 0.01 \mathrm{a}$ & $1.80 \pm 0.14 \mathrm{ab}$ & $15.82 \pm 1.13 \mathrm{a}$ & $2.17 \pm 0.05 \mathrm{~b}$ & $1.33 \pm 0.03 \mathrm{a}$ \\
\hline \multirow[t]{2}{*}{ BCW } & No & $1.25 \pm 0.06 \mathrm{a}$ & $0.10 \pm 0.00 \mathrm{a}$ & $1.95 \pm 0.19 \mathrm{ab}$ & $15.61 \pm 0.46 \mathrm{a}$ & $0.56 \pm 0.05 \mathrm{de}$ & $0.42 \pm 0.05 \mathrm{~cd}$ \\
\hline & Yes & $1.29 \pm 0.06 \mathrm{a}$ & $0.10 \pm 0.01 \mathrm{a}$ & $1.91 \pm 0.17 \mathrm{ab}$ & $8.84 \pm 0.26 \mathrm{c}$ & $0.28 \pm 0.05 \mathrm{e}$ & $0.19 \pm 0.05 \mathrm{~d}$ \\
\hline \multirow[t]{2}{*}{ BIO } & No & $1.06 \pm 0.08 \mathrm{a}$ & $0.09 \pm 0.00 \mathrm{a}$ & $2.32 \pm 0.20 \mathrm{a}$ & $17.01 \pm 0.78 \mathrm{a}$ & $0.74 \pm 0.06 \mathrm{~cd}$ & $0.65 \pm 0.05 \mathrm{bc}$ \\
\hline & Yes & $1.18 \pm 0.10 \mathrm{a}$ & $0.11 \pm 0.01 \mathrm{a}$ & $1.99 \pm 0.22 \mathrm{ab}$ & $11.61 \pm 0.97 \mathrm{bc}$ & $2.80 \pm 0.17 \mathrm{a}$ & $1.16 \pm 0.03 \mathrm{a}$ \\
\hline \multicolumn{2}{|l|}{$\mathrm{LSD}_{0.05}$} & 0.35 & 0.04 & 0.83 & 3.92 & 0.44 & 0.43 \\
\hline \multicolumn{8}{|l|}{ Barley grain } \\
\hline \multirow[t]{2}{*}{ Control } & No & $0.85 \pm 0.05 \mathrm{a}$ & $0.08 \pm 0.00 \mathrm{a}$ & $7.46 \pm 0.52 b$ & $4.50 \pm 0.25 \mathrm{a}$ & $0.96 \pm 0.02 \mathrm{a}$ & $0.41 \pm 0.08 \mathrm{a}$ \\
\hline & Yes & $1.03 \pm 0.02 \mathrm{a}$ & $0.10 \pm 0.01 \mathrm{a}$ & $9.60 \pm 1.07 \mathrm{ab}$ & $4.57 \pm 0.13 \mathrm{a}$ & $1.09 \pm 0.13 \mathrm{a}$ & $0.19 \pm 0.03 \mathrm{a}$ \\
\hline \multirow[t]{2}{*}{ FYM } & No & $0.85 \pm 0.18 \mathrm{a}$ & $0.08 \pm 0.01 \mathrm{a}$ & $8.44 \pm 0.41 \mathrm{~b}$ & $4.79 \pm 0.25 \mathrm{a}$ & $1.01 \pm 0.05 \mathrm{a}$ & $0.40 \pm 0.08 \mathrm{a}$ \\
\hline & Yes & $1.16 \pm 0.13 \mathrm{a}$ & $0.10 \pm 0.01 \mathrm{a}$ & $8.57 \pm 0.58 b$ & $3.98 \pm 0.36 \mathrm{a}$ & $1.10 \pm 0.01 \mathrm{a}$ & $0.44 \pm 0.05 \mathrm{a}$ \\
\hline \multirow[t]{2}{*}{$\mathrm{BCW}$} & No & $0.81 \pm 0.03 \mathrm{a}$ & $0.08 \pm 0.00 \mathrm{a}$ & $7.93 \pm 0.88 b$ & $4.76 \pm 0.25 \mathrm{a}$ & $0.99 \pm 0.04 \mathrm{a}$ & $0.33 \pm 0.09 \mathrm{a}$ \\
\hline & Yes & $1.09 \pm 0.11 \mathrm{a}$ & $0.09 \pm 0.01 \mathrm{a}$ & $8.48 \pm 0.90 b$ & $4.45 \pm 0.08 \mathrm{a}$ & $0.99 \pm 0.03 \mathrm{a}$ & $0.29 \pm 0.05 \mathrm{a}$ \\
\hline \multirow[t]{2}{*}{ BIO } & No & $0.90 \pm 0.07 \mathrm{a}$ & $0.08 \pm 0.00 \mathrm{a}$ & $12.72 \pm 0.77 \mathrm{a}$ & $4.95 \pm 0.18 \mathrm{a}$ & $0.97 \pm 0.01 \mathrm{a}$ & $0.33 \pm 0.02 \mathrm{a}$ \\
\hline & Yes & $1.29 \pm 0.08 \mathrm{a}$ & $0.10 \pm 0.00 \mathrm{a}$ & $8.99 \pm 0.77 \mathrm{ab}$ & $4.21 \pm 0.31 \mathrm{a}$ & $0.99 \pm 0.02 \mathrm{a}$ & $0.32 \pm 0.01 \mathrm{a}$ \\
\hline $\mathrm{LSD}_{0.05}$ & & 0.48 & 0.04 & 3.74 & 1.10 & 0.26 & 0.29 \\
\hline
\end{tabular}

Control, unamended treatment; $F Y M$, farmyard manure; $B C W$, brown coal waste; $B I O$, conifer woodchip biochar; $N P K$, mineral fertiliser. Values represent mean \pm standard error of treatment, $n=3$. Different letters indicate significant differences $(p<0.05)$ between treatment means

Instead, uptakes were higher with FYM than BIO which again is indicative of the ostensibly greater sorption and slow-release mechanisms of BIO for $\mathrm{K}$. However, in potato which is known to be ' $\mathrm{K}-$ loving', the organic amendments, including FYM, failed to increase tuber $\mathrm{K}$ contents to within the critical sufficiency range of 2.2-2.5\% DM (22$25 \mathrm{~g} \mathrm{~kg}^{-1}$ ) proposed by Naumann et al. (2020). Crop nutrient composition is a result of an interplay of complex interactions in soil and redistribution in tissues, and especially for $\mathrm{K}$, increased soil availability does not correspond to increased plant tissue 
$\mathrm{K}$ contents, but, rather, increased tissue $\mathrm{Mg}$ contents according to White et al. (2009). This is consistent with observations from the second year of this study where the highest plant-available $\mathrm{K}$ content found in the FYM treatments did not affect tuber $\mathrm{K}$ content but led to increased potato tuber $\mathrm{Mg}$ content.

The FYM treatment increased Ca uptake in maize and had no effects on potato and barley, but NPK significantly increased uptakes in all crops (Table 2). This led to higher Ca contents in maize and potato (with NPK) but no effect on barley (Table 3). The BIO and $\mathrm{BCW}$ treatments did not affect $\mathrm{Ca}$ uptakes by potato which increased in maize and decreased in barley. Except for a reduction in the BCW treatment, NPK addition did not affect $\mathrm{Ca}$ uptakes by all crops. There were no effects of $\mathrm{BIO}$ and $\mathrm{BCW}$ on maize and barley grain $\mathrm{Ca}$ contents. However, BIO increased the Ca content of potato tuber, which was decreased by the BCW amendment. The addition of NPK had no clear effects on the tissue contents of all crops. Generally, the effects of amendment on $\mathrm{Ca}$ uptake across the three crops were in the order: $\mathrm{FYM}>\mathrm{BCW}>\mathrm{BIO}$ and led to respective 38.3, 21.7 and $17.3 \%$ increases in mean uptakes which were higher with NPK (Table S1). The FYM treatment increased $\mathrm{Mg}$ uptakes in all crops which increased further with NPK except for maize where no effect was found (Table 2). However, the Mg content only increased in potato tuber, with no effects on the maize and barley grains, both with and without NPK (Table 3). Except for potato which had a lower Mg uptake in the $\mathrm{BCW}$ treatment, uptakes were increased across crops in the $\mathrm{BIO}$ and $\mathrm{BCW}$ treatments with no clear effects from NPK addition. The Mg contents of potato were higher with $\mathrm{BIO}$ but lower with $\mathrm{BCW}$ compared with the control, whereas no effects on the maize and barley contents were found. The effects of amendment on uptakes of $\mathrm{Mg}$ across the three crops were in the order: $\mathrm{FYM}>\mathrm{BCW}>\mathrm{BIO}$ and led to respective $43.9,23.4$ and $21.6 \%$ increases in mean uptakes which were higher with NPK (Table S1). While the FYM was the most efficient for increasing the uptakes of $\mathrm{Ca}$ and $\mathrm{Mg}$, the preferential increase in the uptake of $\mathrm{Mg}$ over $\mathrm{Ca}$ by $\mathrm{BIO}$ was observed and has been previously suggested by Syuhada et al. (2016) who reported respective increases and declines in maize grain $\mathrm{Mg}$ and $\mathrm{Ca}$ contents with biochar amendment. Relative to the other nutrients, the lower $\mathrm{Ca}$ and $\mathrm{Mg}$ uptakes and the resultant tissue contents from the amendments were attributable to antagonistic effects

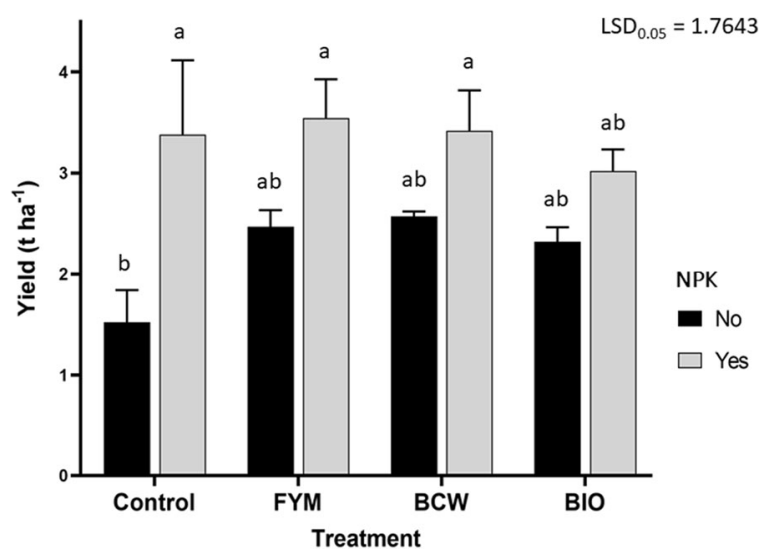

Fig. 11 Maize yield (dry matter) under different organic amendments. Control, unamended treatment; FYM, farmyard manure; $B C W$, brown coal waste; $B I O$, conifer woodchip biochar; $N P K$, mineral fertiliser. Bars represent mean \pm standard error of treatment, $n=3$. Different letters indicate significant differences $(p<$ 0.05 ) between treatments

of $\mathrm{K}$, which is in agreement with findings by other researchers (Butnan et al. 2015), especially considering the high uptakes of $\mathrm{K}$ by the studied crops. In addition, the movements and uptakes of $\mathrm{Mg}$ and $\mathrm{Ca}$ in soil are predominantly via mass flow and passive transport (El-Ramady et al. 2014). These, compared with corresponding diffusive and active transport mechanisms for $\mathrm{N}, \mathrm{P}$ and $\mathrm{K}$ which are also required by plants in higher quantities, may provide additional explanation for the lower uptakes and tissue contents of the former group (Tables 2 and 3).

In the FYM treatments both with and without NPK addition, there were no increases in $\mathrm{S}$ uptakes by maize and barley, while uptakes by potato increased, but there were no effects on the tissue contents of all the crops (Tables 2 and 3). Except for maize which had reduced uptake with NPK, there were no effects of BIO on crop $\mathrm{S}$ uptakes both with and without NPK. The BCW treatment increased maize and barley uptakes but had no effect on potato uptake, whereas NPK reduced maize uptake but had no effects on potato and barley. There were, however, no effects of $\mathrm{BIO}$ and $\mathrm{BCW}$ on the $\mathrm{S}$ contents of all crop tissues. Altogether, the effects of amendments on the uptakes of S by all crops were in the order: $\mathrm{BCW}>\mathrm{FYM}>\mathrm{BIO}$ and resulted in respective $23.4,13.3$ and $7.1 \%$ increases in mean uptakes which were higher with NPK (Table S1). Increased soil S availability reportedly increases plant $\mathrm{S}$ uptakes and contents (Orman and Ok 2012). However, considering 
the insignificant impacts of all organic amendments on residual $\mathrm{S}$ content, the clearest hint for the high $\mathrm{S}$ uptakes in the BCW treatments is the high $\mathrm{S}$ content of $\mathrm{BCW}$ relative to FYM and $\mathrm{BIO}$ (Table 1).

The single application of organic amendments, compared with the positive interactive effects from their combination with NPK fertilisation, led to higher nutrient uptakes. Although tissue nutrient contents were generally not responsive to amendments, deficiencies were higher in the organic-only treatments, especially with $\mathrm{BIO}$ and $\mathrm{BCW}$ due to a higher nutrient sorption and, consequently, lower soil availability as observed in this study. Responses of the nutrient contents of maize leaves and barley straw have been provided in Table S2. From a short-term perspective, the FYM treatments had overall the highest nutrient use efficiency, which was also substantially improved for N, P, K and $\mathrm{S}$ with BCW and then $\mathrm{P}$ and $\mathrm{K}$ with BIO. Similarly, Syuhada et al. (2016) reported increased N, Mg and Ca deficiencies with biochar when applied to soil without inorganic fertilisers. Although a drawback in the shortterm (compared with FYM), the low nutrient release rates of the carbonised organic amendments, especially of BIO, is indicative of potential long-term benefits that can be supplemented through rationing with NPK.

\subsubsection{Crop Yield}

Significant maize yield responses were observed in all treatments both with and without NPK application, leading to respective yield increases of 133.3 and $62.5 \%$ with FYM, 125.0 and $68.9 \%$ with BCW and then 98.7 and $52.76 \%$ with BIO in the first year (Fig. 11). The maize yield increase from the NPK (only) treatment was $122.6 \%$. In the second year, potato yield increases were 33.3 and $13.4 \%$ with FYM, 13.9 and $12.9 \%$ with $\mathrm{BCW}$ and then 5.4 and $2.8 \%$ with BIO. The potato yield increase from the NPK (only) treatment was $14.0 \%$ (Fig. 12). In the third year, barley yield increases were 48.5 and $22.2 \%$ with FYM, 41.5 and $18.7 \%$ with $\mathrm{BCW}$ and then 40.4 and $9.9 \%$ with BIO, whereas $30.4 \%$ from the NPK (only) treatment (Fig. 13).

Similar to our results, there are other welldocumented reports of improved yields of a range of crops from typical application rates $\left(10-40 \mathrm{t} \mathrm{ha}^{-1}\right)$ of FYM, BCW and BIO (Shakoor et al. 2015; Eprikashvili et al. 2016; Faloye et al. 2017; Akimbekov et al. 2020), although some have reported remote or negative yield responses (Diacono and Montemurro 2011; Tahir et al.
2011; Jeffery et al. 2017; Chen et al. 2018; Kováčik et al. 2016). From a range of crops grown in acidic soils, it was reported that biochar amendment led to a median yield increase of $20 \%$ (Jeffery et al. 2017), while compost amendment resulted in maximum yield increases of $13.6 \%$, and thus the mean increases in yields of maize, potato and barley from FYM (32.7\%), BCW (33.5\%) and BIO (21.8\%) amendments in this study compare well. The mean yield increases, as expected, were significantly higher with NPK addition in the FYM (71.7\%), BCW (60.1\%) and $\mathrm{BIO}(48.2 \%)$ treatments due to positive interactive effects between organic amendments and NPK which increased nutrient use efficiency. This is consistent with other findings on grain and tuber crops (including our test crops) which reported lower yield increases from organic (only) treatments compared with inorganic fertiliser treatments, but substantially higher when organic and inorganic fertilisers were combined (Faloye et al. 2017; Chen et al. 2018). However, there were some instances (maize and potato) where yields from NPK only were higher than those from the BIO+NPK treatment (Figs. 11 and 12). Other studies have also found negative or no interactive yield effects from the combined use of biochar and NPK (Jeffery et al. 2011; Martinsen et al. 2014). This could imply a stronger sorption and slower release of the yield-limiting nutrients by $\mathrm{BIO}$ relative to $\mathrm{BCW}$ and FYM. In addition, the biological $\mathrm{N}$ immobilisation potential, which is higher in $\mathrm{BIO}$ compared with $\mathrm{BCW}$ and FYM (Table 1), has been suggested in previous

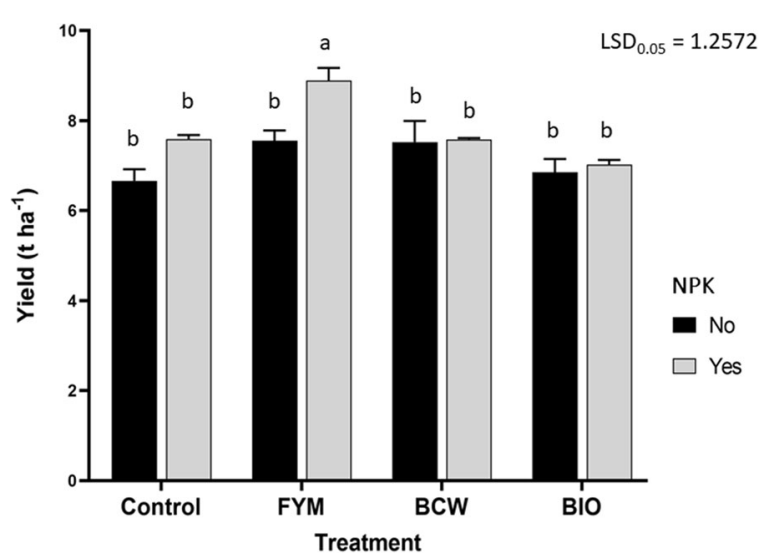

Fig. 12 Potato yield (dry matter) under different organic amendments. Control, unamended treatment; $F Y M$, farmyard manure; $B C W$, brown coal waste; $B I O$, conifer woodchip biochar; $N P K$, mineral fertiliser. Bars represent mean \pm standard error of treatment, $n=3$. Different letters indicate significant differences $(p<$ $0.05)$ between treatments 


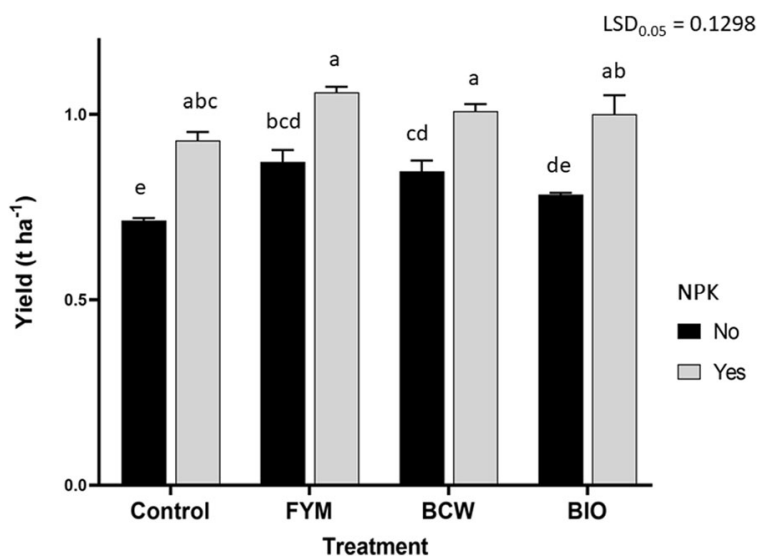

Fig. 13 Barley yield (dry matter) under different organic amendments. Control, unamended treatment; $F Y M$, farmyard manure; $B C W$, brown coal waste; $B I O$, conifer woodchip biochar; $N P K$, mineral fertiliser. Bars represent mean \pm standard error of treatment, $n=3$. Different letters indicate significant differences $(p<$ 0.05 ) between treatments

studies as a reason for lower yields from BIO (Sika 2012; Syuhada et al. 2016). An interesting observation was that when applied alone, $\mathrm{BCW}$, with relatively lower nutrient contents, had a comparable mean yield increase to FYM, thus indicating ancillary soil quality benefits of BCW. Although FYM was more effective when combined with NPK, this is promising for BCW and provides credence to its use as a fertiliser but will require further validation from longer studies using a range of crops. Also notable with regard to the carbonised amendments are their extremely low heavy metal contents (Table 1) which ensured negligible phytotoxicity risks on crop productivity contrary to other studies on $\mathrm{BCW}$ applications which have reported severe effects of heavy metal contamination on crop yield (Leszczyńska and KwiatkowskaMalina 2011; Nzediegwu et al. 2019).

In the present study, there were high yield increases (maize and barley) despite minimal treatment effects on the limiting nutrients, $\mathrm{N}$ and $\mathrm{P}$. This corroborates the Liebscher theory, formalised by the Michaelis-Menten model which recognises other soil parameters as colimiting plant growth factors, among which positive interaction can lead to increased production even at suboptimal levels of the main limiting factors (Nijland and Schouls 1997). Further support to the multifactorial treatment effects can be deduced from the correlations between crop yields and macronutrient contents of soil and plant tissues, which were mostly weak and had no clear trends (Fig. S2-4). This, however, was expected due to the continuous cycling of nutrients from soil through plant uptake and their subsequent redistribution in tissues for biomass production.

\subsection{Holistic Assessment}

In addition to the soil quality, environmental and agronomic benefits, the selection criteria for organic amendments must integrate factors such as material availability, cost, application needs, safety compliance and sustainability (Table 4). For instance, due to the high moisture content and poor field conditions of FYM, it cannot be stored near water courses or applied during winter, whereas the relatively lower moisture contents of BIO and $\mathrm{BCW}$ and ease of water evaporation upon exposure to air allow for a more conducive and year-round field storage and application (Krol-Domańska and Smolinska 2012; Sahoo et al. 2016). This also implies a relatively higher load of pathogenic microorganisms in FYM which carry environmental and public health risks and increased costs when treated (e.g. anaerobic digestion) prior to land application (Nag et al. 2020). Biochar can be produced from a myriad of feedstock (e.g. farm and municipal wastes), and the gradual shift from coal to more sustainable energy sources has created large global reserves of $\mathrm{BCW}$, and hence, like $\mathrm{FYM}$, these carbonised amendments have worldwide applicability (Amoah-Antwi et al. 2020a; Barros et al. 2020). Therefore, the utilisation of variable sources of organic amendments such as $\mathrm{BIO}$ and $\mathrm{BCW}$ contributes to the recovery and valorisation of organic wastes which have implications for the circular economy and sustainability (Barros et al. 2020; Pranagal and Kraska 2020).

Biochar and $\mathrm{BCW}$ are more soil-stable than FYM, and therefore, soils would have lower long-term application needs and better environmental health prospects, which have both labour- and cost-saving benefits. Due to the retention and slow nutrient release mechanisms of biochar and $\mathrm{BCW}$, they are also essential for addressing the problem of low nutrient use efficiency (30-35\%) in arable cropping systems (Galloway et al. 2008; Li et al. 2019) to save on inorganic fertiliser costs. Particularly, the additional cost-benefits of $\mathrm{BCW}$ use is a reason for its emergence as a soil amendment especially in Eastern Europe (e.g. Poland and Slovakia) and Australia (Kwiatkowska et al. 2008; Rose et al. 2016). For example, the Greenpower Energy Limited 
Table 4 Overview of environmental, agronomic and economic factors for the holistic assessment of organic amendments used in cropping systems

\begin{tabular}{|c|c|c|c|c|c|}
\hline \multirow{2}{*}{\multicolumn{2}{|c|}{ Factors }} & \multicolumn{3}{|c|}{ Measure } & \multirow{2}{*}{ References } \\
\hline & & \multirow{2}{*}{$\begin{array}{c}\text { BIO } \\
\checkmark\end{array}$} & \multirow{2}{*}{$\frac{\text { BCW }}{\checkmark}$} & \multirow{2}{*}{$\begin{array}{c}\text { FYM } \\
\checkmark\end{array}$} & \\
\hline \multirow[t]{11}{*}{ Soil quality } & Soil organic matter & & & & \multirow{11}{*}{$\begin{array}{l}\text { Diacono and Montemurro 2011; } \\
\text { Bekele et al. 2015; Agegnehu et al. } \\
\text { 2016; Syuhada et al. 2016; Chen et } \\
\text { al. 2018; Kizito et al. 2019; } \\
\text { Akimbekov et al. 2020; Amoah- } \\
\text { Antwi et al. 2020a, b; Lopes et al. } \\
\text { 2020; Pranagal and Kraska } 2020\end{array}$} \\
\hline & Soil structure & $\checkmark$ & $\checkmark$ & $\checkmark$ & \\
\hline & Water retention/infiltration & $\checkmark$ & $\checkmark$ & $\checkmark$ & \\
\hline & Soil pH & $\checkmark$ & $x$ & $\checkmark$ & \\
\hline & Cation exchange capacity & $\checkmark$ & $\checkmark$ & $\checkmark$ & \\
\hline & Contaminant immobilisation & $\checkmark$ & $\checkmark$ & $\checkmark$ & \\
\hline & Carbon sequestration & $\checkmark$ & $\checkmark$ & $x$ & \\
\hline & Enzyme/ microbial activity & $x$ & $x$ & $\checkmark$ & \\
\hline & Humic acid content & $\checkmark$ & $\checkmark$ & $x$ & \\
\hline & Humic acid quality & $\checkmark$ & $\checkmark$ & $x$ & \\
\hline & Pathogen growth inhibitiom & $\checkmark$ & $\checkmark$ & $\checkmark$ & \\
\hline \multirow[t]{4}{*}{ Air quality } & GHG emissions & $\checkmark$ & $\checkmark$ & $x$ & \multirow{4}{*}{$\begin{array}{l}\text { Agegnehu et al. 2016; Mandal et al. } \\
\text { 2016; Rose et al. 2016; Liu et al. } \\
\text { 2017; Petersen, 2018; Ng et al. } 2020\end{array}$} \\
\hline & Ammonia emisions & $\checkmark$ & $\checkmark$ & $x$ & \\
\hline & Emission of VOCs & $\checkmark$ & $\checkmark$ & $x$ & \\
\hline & Stench/Odour & $\checkmark$ & $\checkmark$ & $x$ & \\
\hline \multirow[t]{6}{*}{ Water quality } & Nutrient leaching & $\checkmark$ & $\checkmark$ & $x$ & \multirow{6}{*}{$\begin{array}{l}\text { Yao et al. 2012; Gao and DeLuca } \\
\text { 2016; Haider et al. 2017; Liu et al. } \\
\text { 2017; Saha et al. 2018; Amoah- } \\
\text { Antwi et al. 2020b; Nag et al. } 2020\end{array}$} \\
\hline & Leaching of PAHs & $\checkmark$ & $\checkmark$ & $\checkmark$ & \\
\hline & Metal leaching & $\checkmark$ & $\checkmark$ & $x$ & \\
\hline & Acidification & $\checkmark$ & $\checkmark$ & $x$ & \\
\hline & Agrochemical leaching & $\checkmark$ & $\checkmark$ & $x$ & \\
\hline & Eutrophication of surface waters & $\checkmark$ & $\checkmark$ & $x$ & \\
\hline \multirow[t]{6}{*}{ Agronomic benefits } & Soil fertility & $x$ & $x$ & $\checkmark$ & \multirow{4}{*}{$\begin{array}{l}\text { Syuhada et al. 2016; Chen et al. } \\
\text { 2018; Celestina et al. 2019; Tisserant } \\
\text { and Cherubini 2019; Akimbekov et } \\
\text { al. 2020; }\end{array}$} \\
\hline & Slow nutrient release & $\checkmark$ & $\checkmark$ & $x$ & \\
\hline & Nutrient cycling & $\checkmark$ & $\checkmark$ & $\checkmark$ & \\
\hline & Plant nutrient uptake & $\checkmark$ & $\checkmark$ & $\checkmark$ & \\
\hline & Crop yield & $\checkmark$ & $\checkmark$ & $\checkmark$ & \\
\hline & Nutritional quality of crop & $\checkmark$ & $\checkmark$ & $\checkmark$ & \\
\hline \multirow[t]{5}{*}{ Availability and cost } & Local availability & $\checkmark$ & $\checkmark$ & $\checkmark$ & \multirow{5}{*}{$\begin{array}{l}\text { Krol-Domańska and Smolinska } \\
\text { 2012; Amoah-Antwi et al. 2020a; Ng } \\
\text { et al. 2020; Pranagal and Kraska } \\
2020 \text {. }\end{array}$} \\
\hline & Transportation and storage & $\checkmark$ & $\checkmark$ & $x$ & \\
\hline & Field production & $\checkmark$ & $x$ & $\checkmark$ & \\
\hline & Amendment cost & $x$ & $\checkmark$ & $\checkmark$ & \\
\hline & Net abatement cost & $\checkmark$ & $\checkmark$ & $x$ & \\
\hline \multirow[t]{4}{*}{ Safety Compliance } & Metal content of amendment & $\checkmark$ & $\checkmark$ & $\checkmark$ & \multirow{4}{*}{$\begin{array}{l}\text { Leszczyńska and Kwiatkowska- } \\
\text { Malina 2011; Bai et al. 2013; } \\
\text { Amoah-Antwi et al. 2020a, b; Nag et } \\
\text { al. } 2020 \text {. }\end{array}$} \\
\hline & Microbial content of amendment & $\checkmark$ & $\checkmark$ & $x$ & \\
\hline & Moisture content regulation & $\checkmark$ & $\checkmark$ & $x$ & \\
\hline & Regulatory compliance & $\checkmark$ & $\checkmark$ & $\checkmark$ & \\
\hline \multirow[t]{5}{*}{ Application and sustainability } & Application rate/ frequency & $\checkmark$ & $\checkmark$ & $x$ & \multirow{5}{*}{$\begin{array}{l}\text { Kwiatkowska-Malina 2015; Weng et } \\
\text { al. 2017; Amoah-Antwi et al. 2020a; } \\
\text { Barros et al. } 2020 .\end{array}$} \\
\hline & Year-round application & $\checkmark$ & $\checkmark$ & $x$ & \\
\hline & Ease of application & $\checkmark$ & $\checkmark$ & $x$ & \\
\hline & Long-term soil stability & $\checkmark$ & $\checkmark$ & $x$ & \\
\hline & Sustainability index & $\checkmark$ & $\checkmark$ & $x$ & \\
\hline
\end{tabular}

$B I O$, woodchip biochar; $B C W$, brown coal waste; $F Y M$, farmyard manure; $G H G$, greenhouse gas; $V O C s$, volatile organic compounds; $P A H s$, polycyclic aromatic hydrocarbons. Irrespective of the connotation of a factor, a check $(\checkmark)$ indicates an advantageous quality/effect of the corresponding amendment while a cross $(\mathbf{x})$, a disadvantage

(ASX:GPP), Australia, produces a BCW bio-fertiliser via an environmentally friendly oxidative hydrothermal dissolution process at just $10 \%$ of the cost of traditional fertilisers (Next Investors 2017). The cost-benefits of replacing manure with $\mathrm{BCW}$ from the net shift in $\mathrm{CO}_{2}$ and $\mathrm{NH}_{3}$ emissions (and abated cost of transport) is estimated to be AUD\$18-256 per cattle per year at BCW application rate of $6 \mathrm{~kg} \mathrm{~m}^{-2}$ 
(Ng et al. 2020). For biochar produced from wood like BIO used in the present study, the net avoided greenhouse emissions per dry tonne of feedstock converted into biochar is estimated to be 45-366 kiloton (Teichmann 2015), and this has significant abatement cost-benefits.

\section{Conclusions}

Our findings indicated that compared with FYM, biochar and BCW applications have longer-lasting soil quality benefits, lower pollution and environmental footprints and then greater safety and sustainability indices which are associated with reduced net abatement costs. Results from the agronomic field trial showed crop yield increases from $\mathrm{BIO}$ and $\mathrm{BCW}$ treatments to be at least $20 \%$ with or without NPK addition. Although these were slightly lower compared with FYM, the greater soil stability of $\mathrm{BIO}$ and $\mathrm{BCW}$ has potential advantages in terms of sustainable long-term productivity. Environmental and agricultural ecosystems are closely knit and overlap in several aspects with links to economics, and therefore, preliminary risk-benefit assessments of new management approaches (e.g. organic amendment use) by stakeholders including agronomists, environmentalists and policymakers should be holistic. From an integrated and sustainable agroecosystem perspective, $\mathrm{BIO}$ and $\mathrm{BCW}$ provide several advantages over FYM, and therefore, their merits for soil management should be explored by future studies.

Supplementary Information The online version contains supplementary material available at https://doi.org/10.1007/s11270021-05044-z.

Acknowledgements This research is part of a project that has received funding from the European Union's Horizon 2020 research and innovation programme under the Marie SkłodowskaCurie grant agreement No 675120.

Open Access This article is licensed under a Creative Commons Attribution 4.0 International License, which permits use, sharing, adaptation, distribution and reproduction in any medium or format, as long as you give appropriate credit to the original author(s) and the source, provide a link to the Creative Commons licence, and indicate if changes were made. The images or other third party material in this article are included in the article's Creative Commons licence, unless indicated otherwise in a credit line to the material. If material is not included in the article's Creative
Commons licence and your intended use is not permitted by statutory regulation or exceeds the permitted use, you will need to obtain permission directly from the copyright holder. To view a copy of this licence, visit http://creativecommons. org/licenses/by/4.0/.

\section{References}

Agegnehu, G., Bass, A. M., Nelson, P. N., \& Bird, M. I. (2016). Benefits of biochar, compost and biochar-compost for soil quality, maize yield and greenhouse gas emissions in a tropical agricultural soil. Science of the Total Environment, 543, 295-306. https://doi.org/10.1016/j.scitotenv.2015.11.054.

Akimbekov, N., Qiao, X., Digel, I., Abdieva, G., Ualieva, P., \& Zhubanova, A. (2020). The effect of leonardite-derived amendments on soil microbiome structure and potato yield. Agriculture, 10, 147. https://doi.org/10.3390 /agriculture10050147.

Amoah-Antwi, C., Kwiatkowska-Malina, J., Thornton, S. F., Fenton, O., Malina, G., \& Szara, E. (2020a). Restoration of soil quality using biochar and brown coal waste: A review. Science of the Total Environment, 722, 137852. https://doi. org/10.1016/j.scitotenv.2020.137852.

Amoah-Antwi, C., Kwiatkowska-Malina, J., Szara, E., Thornton, S. F., Fenton, O., \& Malina, G. (2020b). Efficacy of woodchip biochar and brown coal waste as stable sorbents for abatement of bioavailable cadmium, lead and zinc in soil. Water, Air, and Soil Pollution, 231, 515. https://doi. org/10.1007/s11270-020-04885-4.

Arjumend, T., Abbasi, M. K., \& Rafique, E. (2015). Effects of lignite-derived humic acid on some selected soil properties, growth and nutrient uptake of wheat (Triticum aestivum L.) grown under greenhouse conditions. Pakistan Journal of Botany, 47, 2231-2238.

Arthurson, V., \& Jäderlund, L. (2011). Utilization of natural farm resources for promoting high energy efficiency in low-input organic farming. Energies, 4, 804-817. https://doi. org/10.3390/en4050804.

Aziz, M. A., Ahmad, H. R., Corwin, D. L., Sabir, M., Hakeem, R. K., \& Öztürk, M. (2017). Influence of farmyard manure on retention and availability of nickel, zinc and lead in metalcontaminated calcareous loam soils. Journal of Environmental Engineering and Landscape, 25(3), 289296. https://doi.org/10.3846/16486897.2016.1254639.

Bai, Y., Tao, T., Gu, C., Wang, L., Feng, K., \& Shan, Y. (2013). Mudflat soil amendment by sewage sludge: Soil physicochemical properties, perennial ryegrass growth, and metal uptake. Soil Science and Plant Nutrition, 59(6), 942-952. https://doi.org/10.1080/00380768.2013.866522.

Barros, M. V., Salvador, R., de Francisco, A. C., \& Piekarski, C. M. (2020). Mapping of research lines on circular economy practices in agriculture: From waste to energy. Renewable and Sustainable Energy Reviews, 131, 109958. https://doi. org/10.1016/j.rser.2020.109958.

Batista, E. M. C. C., Shultz, J., Matos, T. T. S., Fornari, M. R., Ferreira, T. M., Szpoganicz, B., et al. (2018). Effect of surface and porosity of biochar on water holding capacity aiming indirectly at preservation of the Amazon biome. 
Science Reports, 8, 10677. https://doi.org/10.1038/s41598018-28794-z.

Bekele, A., Roy, J. L., \& Young, M. A. (2015). Use of biochar and oxidized lignite for reconstructing functioning agronomic topsoil: Effects on soil properties in a greenhouse study. Canadian Journal of Soil Science, 95, 269-285. https://doi. org/10.4141/cjss-2014-008.

Belay, A., Claassens, A. S., \& Wehner, F. C. (2002). Soil nutrient contents, microbial properties and maize yield under longterm legume-based crop rotation and fertilization: A comparison of residual effect of manure and NPK fertilizers. South African Journal of Plant and Soil, 19(2), 104-110. https://doi.org/10.1080/02571862.2002.10634447.

Biederman, L. A., \& Harpole, W. S. (2013). Biochar and its effects on plant productivity and nutrient cycling: A meta-analysis. GCB Bioenergy, 5, 202-214. https://doi.org/10.1111 /gcbb.12037.

Bista, P., Ghimire, R., Machado, S., \& Pritchett, L. (2019). Biochar effects on soil properties and wheat biomass vary with fertility management. Agronomy, 9, 623. https://doi. org/10.3390/agronomy9100623.

Burrell, L. D., Zehetner, F., Rampazzo, N., Wimmer, B., \& Soja, G. (2016). Long-term effects of biochar on soil physical properties. Geoderma, 282, 96-102.17C. https://doi. org/10.1016/j.geoderma.2016.07.019.

Butnan, S., Deenik, J. L., Toomsan, B., Antal, M. J., \& Vityakona, P. (2015). Biochar characteristics and application rates affecting corn growth and properties of soils contrasting in texture and mineralogy. Geoderma, 237-238, 105-116. https://doi.org/10.1016/j.geoderma.2014.08.010.

Celestina, C., Hunt, J. R., Sale, P. W. G., \& Franks, A. E. (2019). Attribution of crop yield responses to application of organic amendments: A critical review. Soil and Tillage Research, 186, 135-145. https://doi.org/10.1016/j.still.2018.10.002.

Chen, Y., Camps-Arbestain, M., Shen, Q., Singh, B., \& Cayuela, M. L. (2018). The long-term role of organic amendments in building soil nutrient fertility: A meta-analysis and review. Nutrient Cycling in Agroecosystems, 111, 103-125. https://doi.org/10.1007/s10705-017-9903-5.

Ciećko, Z., Żołnowski, A. C., Madej, M., Wasiak, G., \& Lisowski, J. (2015). Long-term effects of hard coal fly ash on selected soil properties. Polish Journal of Environmental Studies, 24(5), 1949-1957.

Clark, M. S., Horwath, W. R., Shennan, C., \& Scow, K. M. (1998). Changes in soil chemical properties resulting from organic and low-input farming practices. Agronomy Journal, $90,662-671$. https://doi.org/10.2134 /agronj1998.00021962009000050016x.

Coleman, N. T., \& Mehlich, A. (1957). The chemistry of soil pH. Yearbook of Agriculture (Soil) (pp. 72-79). Washington, DC: Department of Agriculture.

Dębska, B., Maciejewska, A., \& Kwiatkowska, J. (2002). The effect of fertilization with brown coal on Haplic Luvisol humic acids. Rostlinna Vyroba, 48(1), 33-39. https://doi. org/10.17221/4203-PSE.

Diacono, M., \& Montemurro, F. (2011). Long-term effects of organic amendments on soil fertility. In E. Lichtfouse, M. Hamelin, M. Navarrete, \& P. Debaeke (Eds.), Sustainable Agriculture 2. Dordrecht: Springer. https://doi.org/10.1007 /978-94-007-0394-0 34.
El-Ramady, H. R., Alshaal, T. A., Amer, M., DomokosSzabolcsy, E., Elhawat, N., Prokisch, J., \& Fari, M. (2014). Soil quality and plant nutrition. In E. Lichtfouse (Ed.), Sustainable Agriculture Reviews 14 (pp. 345-447). Switzerland: Springer International Publishing. https://doi. org/10.1007/978-3-319-06016-3_11.

Eprikashvili, L., Zautashvili, M., Kordzakhia, T., Pirtskhalava, N., Dzagania, M., Rubashvili, I., \& Tsitsishvili, V. (2016). Intensification of bioproductivity of agricultural cultures by adding natural zeolites and brown coals into soils. Annals of Agrarian Science, 14, 67. https://doi.org/10.1016/j. aasci.2016.05.004.

Faloye, O. T., Alatise, M. O., Ajayi, A. E., \& Ewulo, B. S. (2017). Synergistic effects of biochar and inorganic fertiliser on maize (Zea mays) yield in an alfisol under drip irrigation. Soil and Tillage Research, 174, 214-220. https://doi. org/10.1016/j.still.2017.07.013.

Galloway, J. N., Townsend, A. R., Erisman, J. W., Bekunda, M., Cai, Z., Freney, J. R., et al. (2008). Transformation of the nitrogen cycle: recent trends, questions, and potential solutions. Science, 320, 889-892. https://doi.org/10.1126 /science.1136674.

Gao, S., \& DeLuca, T. H. (2016). Influence of biochar on soil nutrient transformations, nutrient leaching, and crop yield. Advances in Plants and Agriculture Research, 4(5), 348 362. https://doi.org/10.15406/apar.2016.04.00150.

Gao, T., Gao, M., Peng, J., \& Li, N. (2018). Effects of different amount of biochar on nitrogen, phosphorus and potassium nutrients in soil. IOP Conference Series: Materials Science and Engineering, 394, 022043. https://doi.org/10.1088 /1757-899X/394/2/022043.

Griffin, D. E., Wang, D., Parikh, S. J., \& Scow, K. M. (2017). Short-lived effects of walnut shell biochar on soils and crop yields in a long-term field experiment. Agriculture, Ecosystems and Environment, 236, 21-29. https://doi. org/10.1016/j.agee.2016.11.002.

Haider, G., Steffens, D., Moser, G., Müller, C., \& Kammann, C. I. (2017). Biochar reduced nitrate leaching and improved soil moisture content without yield improvements in a four-year field study. Agriculture, Ecosystems and Environment, 237, 80-94. https://doi.org/10.1016/j.agee.2016.12.019.

IUSS Working Group WRB. (2015). World reference base for soil resources 2014, update 2015. International soil classification system for naming soils and creating legends for soil maps. World Soil Resources Reports No. 106. Rome: FAO.

Jeffery, S., Verheijen, F. G. A., van der Velde, M., \& Bastos, A. C. (2011). A quantitative review of the effects of biochar application to soils on crop productivity using meta-analysis. Agriculture, Ecosystems and Environment, 144, 175-187. https://doi.org/10.1016/j.agee.2011.08.015.

Jeffery, S., Abalos, D., Prodana, M., Bastos, A. C., van Groenigen, J. W., Hungate, B. A., et al. (2017). Biochar boosts tropical but not temperate crop yields. Environmental Research Letters, 12, 053001. https://doi.org/10.1088/1748-9326 /aa67bd.

Jia, Y., Li, F. M., Wang, X. L., \& Xu, J. Z. (2006). Dynamics of soil organic carbon and soil fertility affected by alfalfa productivity in a semiarid agroecosystem. Biogeochemistry, 80, 233-243. https://doi.org/10.1007/s10533-006-9020-z.

Káš, M., Mühlbachová, G., Kusá, H., \& Pechová, M. (2016). Soil phosphorus and potassium availability in long-term field 
experiments with organic and mineral fertilization. Plant, Soil and Environment, 62(12), 558-565. https://doi. org/10.17221/534/2016-PSE.

Kaya, C., Șenbayram, M., Akram, N. A., Ashraf, M., Alyemeni, M. N., \& Ahmad, P. (2020). Sulfur-enriched leonardite and humic acid soil amendments enhance tolerance to drought and phosphorus deficiency stress in maize (Zea mays L.). Science Reports, 10, 6432. https://doi.org/10.1038/s41598020-62669-6.

Kizito, S., Luo, H., Lu, J., Bah, H., Dong, R., \& Wu, S. (2019). Role of nutrient-enriched biochar as a soil amendment during maize growth: Exploring practical alternatives to recycle agricultural residuals and to reduce chemical fertilizer demand. Sustainability, 11, 3211. https://doi.org/10.3390 /su11113211.

Kołodziej, B., Bryk, M., \& Otremba, K. (2020). Effect of rockwool and lignite dust on physical state of rehabilitated post-mining soil. Soil \& Tillage Research, 199, 104603. https://doi.org/10.1016/j.still.2020.104603.

Kováčik, P., Žofajová, A., Šimanský, V., \& Halászová, K. (2016). Spring barley yield parameters after lignite, sodium humate and nitrogen utilization. Agriculture (Polnohospodárstvo), 62(3), 80-89. https://doi.org/10.1515/agri-2016-0009.

Krol-Domańska, K., \& Smolinska, B. (2012). Advantages of lignite addition in purification process of soil polluted by heavy metals. Biotechnology and Food Science, 76, 51-58.

Kulhánek, M., Balík, J., Černý, J., Vašák, F., \& Shejbalová, Š. (2014). Influence of long-term fertilizer application on changes of the content of Mehlich-3 estimated soil macronutrients. Plant, Soil and Environment, 60, 151-157. https://doi.org/10.17221/930/2013-PSE.

Kuzyakov, Y., Subbotina, I., Chen, H., Bogomolova, I., \& Xu, X. (2009). Black carbon decomposition and incorporation into soil microbial biomass estimated by $14 \mathrm{C}$ labeling. Soil Biology and Biochemistry, 41, 210-219. https://doi. org/10.1016/j.soilbio.2008.10.016.

Kwiatkowska, J., Provenzano, M. R., \& Senesi, N. (2008). Longterm effects of brown coal-based amendment on the properties of soil humic acids. Geoderma, 148, 200-205.

Kwiatkowska-Malina, J. (2015). The influence of exogenic organic matter on selected chemical and physicochemical properties of soil. Polish Journal of Soil Science, 48, 173. https://doi.org/10.17951/pjss.2015.48.2.173.

Lehmann, J. (2007). Bio-energy in the black. Frontiers in Ecology and the Environment, 5(7), 381-387. https://doi.org/10.1890 /1540-9295(2007)5[381:BITB]2.0.CO;2.

Lemanowicz, J., Siwik-Ziomek, A., \& Koper, J. (2014). Effects of farmyard manure and nitrogen fertilizers on mobility of phosphorus and sulphur in wheat and activity of selected hydrolases in soil. International Agrophysics, 28, 49-55. https://doi.org/10.2478/intag-2013-0026.

Leszczyńska, D., \& Kwiatkowska-Malina, J. (2011). Effect of organic matter from various sources on yield and quality of plant on soils contaminated with heavy metals. Ecological Chemistry and Engineering S, 4, 501-507.

Li, Y., Hu, S., Chen, J., Muller, K., Li, Y., Fu, W., et al. (2018). Effects of biochar application in forest ecosystems on soil properties and greenhouse gas emissions: A review. Journal of Soils and Sediments, 18, 546-563. https://doi.org/10.1007 /s11368-017-1906-y.
Li, Y. L., Cheng, J., Lee, X., Chen, Y., Gao, W., Pan, W., \& Tang, Y. (2019). Effects of biochar-based fertilizers on nutrient leaching in a tobacco-planting soil. Acta Geochimica, 38, 1-7. https://doi.org/10.1007/s11631-018-0307-2.

Little, K. L., Rose, M. T., Jackson, W. R., Cavagnaro, T. R., \& Patti, A. F. (2014). Do lignite-derived organic amendments improve early-stage pasture growth and key soil biological and physicochemical properties? Crop \& Pasture Science, 65, 899-910. https://doi.org/10.1071/CP13433.

Liu, W. J., Li, W. W., Jiang, H., \& Yu, H. Q. (2017). Fates of chemical elements in biomass during its pyrolysis. Chemical Reviews, 117, 6367-6398. https://doi.org/10.1021/acs. chemrev.6b00647.

Lopes, E. M. G., Reis, M. M., Frazão, L. A., da Mata Terra, L. E., Lopes, E. F., dos Santos, M. M., \& Fernandes, L. A. (2020). Biochar increases enzyme activity and total microbial quality of soil grown with sugarcane. Environmental Technology and Innovation, 101270. https://doi.org/10.1016/j. eti.2020.101270.

Lopez-Arredondo, D. L., Leyva-Gonzalez, M. A., AlatorreCobos, F., \& Herrera-Estrella, L. (2013). Biotechnology of nutrient uptake and assimilation in plants. The International Journal of Developmental Biology, 57, 595-610. https://doi. org/10.1387/ijdb.130268lh.

Luo, Y., Durenkamp, M., De Nobili, M., Lin, Q., \& Brookes, P. C. (2011). Short term soil priming effects and the mineralisation of biochar following its incorporation to soils of different $\mathrm{pH}$. Soil Biology and Biochemistry, 43, 2304-2314. https://doi. org/10.1016/j.soilbio.2011.07.020.

Magalhães, A. G., Rolim, M. M., Duarte, A.d. S., da Silva, G. F., Neto, E. B., \& Pedrosa, E. M. R. (2016). Macronutrient and sodium content in maize plants under cassava wastewater fertilization. Revista Brasileira de Engenharia Agrícola e Ambiental, 20, 215-222. https://doi.org/10.1590/1807-1929 /agriambi.v20n3p215-222.

Mahmood, F., Khan, I., Ashraf, U., Shahzad, T., Hussain, S., Shahid, M., Abid, M., \& Ullah, S. (2017). Effects of organic and inorganic manures on maize and their residual impact on soil physico-chemical properties. Journal of Soil Science and Plant Nutrition, 17, 22-32. https://doi.org/10.4067/S071895162017005000002.

Mandal, S., Thangarajan, R., Bolan, N. S., Sarkar, B., Khan, N., Ok, Y. S., \& Naidu, R. (2016). Biochar-induced concomitant decrease in ammonia volatilization and increase in nitrogen use efficiency by wheat. Chemosphere, 142, 120-127. https://doi.org/10.1016/j.chemosphere.2015.04.086.

Martinsen, V., Mulder, J., Shitumbanuma, V., Sparrevik, M., Børresen, T., \& Cornelissen, G. (2014). Farmer-led maize biochar trials: Effect on crop yield and soil nutrients under conservation farming. Journal of Plant Nutrition and Soil Science, 177, 681-695. https://doi.org/10.1002 /jpln.201300590.

Mehlich, A. (1984). Mehlich 3 soil test extractant: A modification of Mehlich 2 extractant. Communications in Soil Science and Plant Analysis, 15, 1409-1416.

Nag, R., Whyte, P., Markey, P. K., O'Flaherty, V., Bolton, D., Fenton, O., Richards, K. G., \& Cummins, E. (2020). Ranking hazards pertaining to human health concerns from land application of anaerobic digestate. Science of the Total Environment, 710, 136297. https://doi.org/10.1016/j. scitotenv.2019.136297. 
Naumann, M., Koch, M., Thiel, H., Gransee, A., \& Pawelzik, E. (2020). The importance of nutrient management for potato production part II: Plant nutrition and tuber quality. Potato Research, 63, 121-137. https://doi.org/10.1007/s11540-01909430-3.

Next Investors (2017). GPP smashing the costs of fertilizer: 1/10th the cost of traditional producers. https://www. nextminingboom.com/gpp-smashing-costs-fertilizer-110thcost-traditional-producers/ (accessed on 14 November 2020).

Ng, E. L., Liang, X., Lam, S. K., Chen, D., \& Weatherley, A. J. (2020). What are the social costs and benefits of lignite application to reduce ammonia emissions in intensive feedlot? Journal of Environmental Management, 269, 110821. https://doi.org/10.1016/j.jenvman.2020.110821.

Nijland, G. O., \& Schouls, J. (1997). The relation between crop yield, nutrient uptake, nutrient surplus and nutrient application. Wageningen Agricultural. University Papers, 97-3.

Novak, J. M., Johnson, M. G., \& Spokas, K. A. (2018). Concentration and release of phosphorus and potassium from lignocellulosic- and manure-based biochars for fertilizer reuse. Frontiers in Sustainable Food Systems, 54, 1-9. https://doi.org/10.3389/fsufs.2018.00054.

Nzediegwu, C., Prasher, S., Elsayed, E., Dhiman, J., Mawof, A., \& Patel, R. (2019). Effect of biochar on heavy metal accumulation in potatoes from wastewater irrigation. Journal of Environmental Management, 232, 153-164. https://doi. org/10.1016/j.jenvman.2018.11.013.

O’Keefe, J. M. K., Bechtel, A., Christanis, K., Dai, S., DiMichele, W. A., Eble, C. F., et al. (2013). On the fundamental difference between coal rank and coal type. International Journal of Coal Geology, 118, 58-87. https://doi.org/10.1016/j. coal.2013.08.007.

Orman, S., \& Ok, H. (2012). Effects of sulfur and zinc applications on growth and nutrition of bread wheat in calcareous clay loam soil. African Journal of Biotechnology, 11(13), 30803086. https://doi.org/10.5897/AJB11.2701.

Ouyang, L., Wang, F., Tang, J., Yu, L., \& Zhang, R. (2013). Effects of biochar amendment on soil aggregates and hydraulic properties. Journal of Soil Science and Plant Nutrition, 13, 991-1002.

Paramashivam, D., Clough, T. J., Carlton, A., Gough, K., Dickinson, N., Horswell, J., et al. (2016). The effect of lignite on nitrogen mobility in a low-fertility soil amended with biosolids and urea. Science of the Total Environment, 543, 601-608. https://doi.org/10.1016/j.scitotenv.2015.11.075.

Pias, O. H. C., Tiecher, T., Cherubin, M. R., Mazurana, M., \& Bayer, C. (2019). Crop yield responses to sulfur fertilization in Brazilian no-till soils: A systematic review. Revista Brasileira de Ciência do Solo, 43, e0180078. https://doi. org/10.1590/18069657rbcs20180078.

Pranagal, J., \& Kraska, P. (2020). 10-Years studies of the soil physical condition after one-time biochar application. Agronomy, 10, 1589. https://doi.org/10.3390 /agronomy10101589.

Qi, Y., Hoadley, A. F. A., Chaffee, A. L., \& Garnier, G. (2011). Characterisation of lignite as an industrial adsorbent. Fuel, 90, 1567-1574. https://doi.org/10.1016/j.fuel.2011.01.015.

Rose, M. T., Perkins, E. L., Saha, B. K., Tang, E. C. W., Cavagnaro, T. R., Jackson, W. R., Hapgood, K. P., Hoadley, A. F. A., \& Patti, A. F. (2016). A slow release nitrogen fertiliser produced by simultaneous granulation and superheated steam drying of urea with brown coal. Chemical and Biological Technologies in Agriculture, 3, 1-14. https://doi.org/10.1186/s40538-016-0062-8.

Saha, B. K., Rose, M. T., Wong, V. N. L., Cavagnaro, T. R., \& Patti, A. F. (2018). Nitrogen dynamics in soil fertilized with slow release brown coal-urea fertilizers. Scientific Reports, 8 , 1-10. https://doi.org/10.1038/s41598-018-32787-3.

Sahoo, P. K., Kim, K., \& Powell, M. A. (2016). Managing groundwater nitrate contamination from livestock farms: Implication for nitrate management guidelines. Current Pollution Reports, 2, 178-187. https://doi.org/10.1007 /s40726-016-0033-5.

Schulz, H., \& Glaser, B. (2012). Effects of biochar compared to organic and inorganic fertilizers on soil quality and plant growth in a greenhouse experiment. Journal of Plant Nutrition and Soil Science, 175, 410-422. https://doi. org/10.1002/jpln.201100143.

Sedberry, J. E., Amacher, M. C., Bligh, D. P., \& Curtis, O. D. (1987). Plant tissue analysis as a diagnostic aid in crop production. Louisiana State University Agricultural Experimental Station Bulletin, 783.

Shakoor, A., Ashraf, M., Shah, L., Ali, A., Khan, A., Sher, A., \& Misbahullah, \& Kamran, M. (2015). Impact of farmyard manure and nitrogen, phosphorus, and potassium on maize crop. Academic Research Journal of Agricultural Science and Research, 3(8), 219-223.

Sika, M.P. (2012). Effect of biochar on chemistry, nutrient uptake and fertilizer mobility in sandy soil. Master's thesis, University of Stellenbosch, Stellenbosch, South Africa.

Soria, R. I., Rolfe, S. A., Betancourth, M. P., \& Thornton, F. S. (2020). The relationship between properties of plant-based biochars and sorption of $\mathrm{Cd}(\mathrm{II}), \mathrm{Pb}(\mathrm{II})$ and $\mathrm{Zn}(\mathrm{II})$ in soil model systems. Heliyon, 6(11), e05388.

Syuhada, A. B., Shamshuddin, C. I., Fauziah, C. I., Rosenani, A. B., \& Arifin, A. (2016). Biochar as soil amendment: Impact on chemical properties and corn nutrient uptake in a Podzol. Canadian Journal of Soil Science, 96, 400-412. https://doi. org/10.1139/cjss-2015-0044.

Tahir, M. M., Khurshid, M., Khan, M. Z., Abbasi, M. K., \& Kazmi, M. H. (2011). Lignite-derived humic acid effect on growth of wheat plants in different soils. Pedosphere, 21(1), 124-131. https://doi.org/10.1016/S1002-0160(10)60087-2.

Teichmann, I. (2015). An economic assessment of soil carbon sequestration with biochar in Germany. Discussion Papers of DIW Berlin 1476, DIW Berlin, German Institute for Economic Research. https://www.diw . de/documents/publikationen/73/diw_01.c.502971.de/dp1476. pdf (Accessed on 30 November 2020)

Tisserant, A., \& Cherubini, F. (2019). Potentials, limitations, cobenefits and tradeoff of biochar application to soil for climate change mitigation. Land, 8, 179. https://doi.org/10.3390 /land8120179.

Tran, C. K. T., Rose, M. T., Cavagnaro, T. R., \& Patti, A. F. (2015). Lignite amendment has limited impacts on soil microbial communities and mineral nitrogen availability. Applied Soil Ecology, 95, 140-150. https://doi.org/10.1016 /j.apsoil.2015.06.020.

Tsetsegmaa, G., Akhmadi, K., Cho, W., Lee, S., Chandra, R., Jeong, C. E., Chia, R. W., \& Kang, H. (2018). Effects of oxidized brown coal humic acid fertilizer on the relative 
height growth rate of three tree species. Forests, 9, 360. https://doi.org/10.3390/f9060360.

Weng, Z., Van Zwieten, L., Singh, B. P., Tavakkoli, E., Joseph, S., Macdonald, L. M., et al. (2017). Biochar built soil carbon over a decade by stabilizing rhizodeposits. Nature Climate Change, 7(5), 371-376. https://doi.org/10.1038/nclimate3276.

White, P. J., Bradshaw, J. E., Finlay, M., Dale, B., Ramsay, G., Hammond, J. P., \& Broadley, M. R. (2009). Relationships between yield and mineral concentrations in potato tubers. HortScience, 44, 6-11. https://doi.org/10.21273 /HORTSCI.44.1.6.

Yao, Y., Gao, B., Zhang, M., Inyang, M., \& Zimmerman, A. R. (2012). Effect of biochar amendment on sorption and leaching of nitrate, ammonium, and phosphate in a sandy soil. Chemosphere, 89, 1467-1471.

Zhang, H., Chen, C., Gray, E. M., \& Boyd, S. E. (2017a). Effect of feedstock and pyrolysis temperature on properties of biochar governing end use efficacy. Biomass and Bioenergy, 105, 136-146. https://doi.org/10.1016/j.biombioe.2017.06.024.

Zhang, X., Han, X., Yu, W., Wang, P., \& Cheng, W. (2017b). Priming effects on labile and stable soil organic carbon decomposition: Pulse dynamics over two years. PLoS One, 12(9), e0184978. https://doi.org/10.1371/journal. pone. 0184978 .

Zimmerman, A. R., Gao, B., \& Ahn, M.-Y. (2011). Positive and negative carbon mineralization priming effects among a variety of biochar-amended soils. Soil Biology and Biochemistry, 43, 1169-1179. https://doi.org/10.1016/j. soilbio.2011.02.005

Publisher's Note Springer Nature remains neutral with regard to jurisdictional claims in published maps and institutional affiliations. 